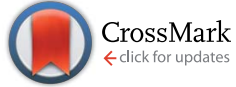

Cite this: J. Mater. Chem. A, 2016, 4, 2705

Received 4th December 2015

Accepted 20th January 2016

DOI: $10.1039 / c 5 t a 09891 b$

www.rsc.org/MaterialsA

\section{Porous GeaC materials via twin polymerization of germanium(II) salicyl alcoholates for Li-ion batteries $\uparrow$}

\author{
Philipp Kitschke, ${ }^{a}$ Marc Walter, ${ }^{b}$ Tobias Rüffer, ${ }^{c}$ Andreas Seifert, ${ }^{d}$ Florian Speck, ${ }^{e}$ \\ Thomas Seyller, ${ }^{e}$ Stefan Spange, ${ }^{d}$ Heinrich Lang, ${ }^{c}$ Alexander A. Auer, ${ }^{f}$ \\ Maksym V. Kovalenko ${ }^{b}$ and Michael Mehring ${ }^{\star a}$
}

\begin{abstract}
The germylenes, germanium(॥) 2-(oxidomethyl)phenolate (1), germanium(॥) 4-methyl-2-(oxidomethyl) phenolate (2) and germanium(II) 4-bromo-2-(oxidomethyl)phenolate (3) were synthesized and their thermally induced twin polymerization to give organic-inorganic hybrid materials was studied. The compounds 1-3 form oligomers including dimers, trimers and tetramers as a result of intermolecular coordination of the benzylic oxygen atom to germanium. The structural motifs were studied by single crystal X-ray diffraction analysis and DFT-D calculations. Thermally induced twin polymerization of these germylenes gave hybrid materials based on germanium-containing phenolic resins. Carbonization of these resins under reductive conditions resulted in porous materials that are composed of germanium and carbon (GeaC materials), while oxidation with air provided non-porous germanium dioxide. The porous GeaC materials were tested as potential anode materials for rechargeable Li-ion batteries. Reversible capacities of $540 \mathrm{~mA} \mathrm{~h} \mathrm{~g}^{-1}$ were obtained at a current density of $346 \mathrm{~mA} \mathrm{~g}^{-1}$ without apparent fading for 100 cycles, which demonstrates that germanium is well accessible in the hybrid material.
\end{abstract}

\section{Introduction}

The chemistry of low valent germanium compounds has been studied intensely within the last four decades, starting with the pioneering work of Curtis, Lappert and Satgé and their coworkers in the $1970 \mathrm{~s} .{ }^{1-5}$ The early studies mainly focused on the use as ligands in transition metal complexes, ${ }^{2,6-10}$ the reactivity in organogermanium chemistry, ${ }^{5,11-13}$ and fundamental

${ }^{a}$ Technische Universität Chemnitz, Fakultät für Naturwissenschaften, Institut für Chemie, Professur Koordinationschemie, 09107 Chemnitz, Germany. E-mail: michael.mehring@chemie.tu-chemnitz.de

${ }^{b}$ Eidgenössische Technische Hochschule Zürich, Department of Chemistry and Applied Biosciences, Laboratory of Inorganic Chemistry, Vladimir-Prelog-Weg 1, 8093 Zürich (Switzerland) and Empa-Swiss Federal Laboratories for Materials Science and Technology, Laboratory for thin films and photovoltaics, Überlandstraße 129, 8600 Dübendorf, Switzerland

${ }^{c}$ Technische Universität Chemnitz, Fakultät für Naturwissenschaften, Institut für Chemie, Professur Anorganische Chemie, 09107 Chemnitz, Germany

${ }^{d}$ Technische Universität Chemnitz, Fakultät für Naturwissenschaften, Institut für Chemie, Professur Polymerchemie, 09107 Chemnitz, Germany

${ }^{e}$ Technische Universität Chemnitz, Fakultät für Naturwissenschaften, Institut für Physik, Professur Experimentalphysik mit dem Schwerpunkt Technische Physik, 09107 Chemnitz, Germany

${ }^{f}$ Max-Planck-Institut für Chemische Energiekonversion, Stiftsstraße 34-36, 45470 Mülheim an der Ruhr, Germany

$\dagger$ Electronic supplementary information (ESI) available. CCDC 1438300-1438303. For ESI and crystallographic data in CIF or other electronic format see DOI: 10.1039/c5ta09891b characterization. ${ }^{\mathbf{1 4 - 1 6}}$ While research on germylenes e.g., as model compounds in addition reactions such as of germanium into $\mathrm{N}-\mathrm{H}$ and $\mathrm{P}-\mathrm{Cl}$ bonds, progressed rapidly, ${ }^{17-27}$ studies focusing on applications e.g., in catalysis ${ }^{28}$ or as precursors for atomic layer deposition, ${ }^{29}$ have rarely been reported until now. Quite recently molecular germanium(II) compounds were used to prepare germanium-based anode materials for Li-ion batteries, ${ }^{30-32}$ motivated by the fact that germanium is a highly promising anode material considering its high gravimetric and volumetric theoretical capacities (1384 mA h g ${ }^{-1} / 7367 \mathrm{~A} \mathrm{~h} \mathrm{~L}^{-1}$ for $\mathrm{Li}_{15} \mathrm{Ge}_{4}$ ), high electrical conductivity and lithium-ion diffusivity. ${ }^{33-41}$ Nevertheless, bulk germanium shows only poor cycling stability due to the large volume changes of up to $246 \%$ upon lithiation and delithiation. Nanostructuring of germanium has been reported as effective method to improve both cycling stability and rate capability, ${ }^{\mathbf{4 2 - 5 4}}$ and following this concept starting from $\mathrm{GeI}_{2}$ (ref. 30) or diphenyl germylene, ${ }^{31,32}$ anode materials exhibiting promising capacity retentions were synthesized. Intrigued by this approach, we decided to adopt the novel concept of twin polymerization (TP) to germylenes. TP is defined as a concerted formation of two polymers in one synthetic step starting from a single monomer (twin monomer) and provides a simple method to obtain nanostructured hybrid materials that can be converted into highly porous materials. ${ }^{55-63}$ Diverse metal salicyl alcoholates ( $\mathrm{M}=\mathrm{Si}$, Ge and $\mathrm{Sn}$ ) have been demonstrated to provide nanostructured organic-inorganic hybrid materials by this novel concept. ${ }^{55,64-67}$ Conversion of such hybrid materials 


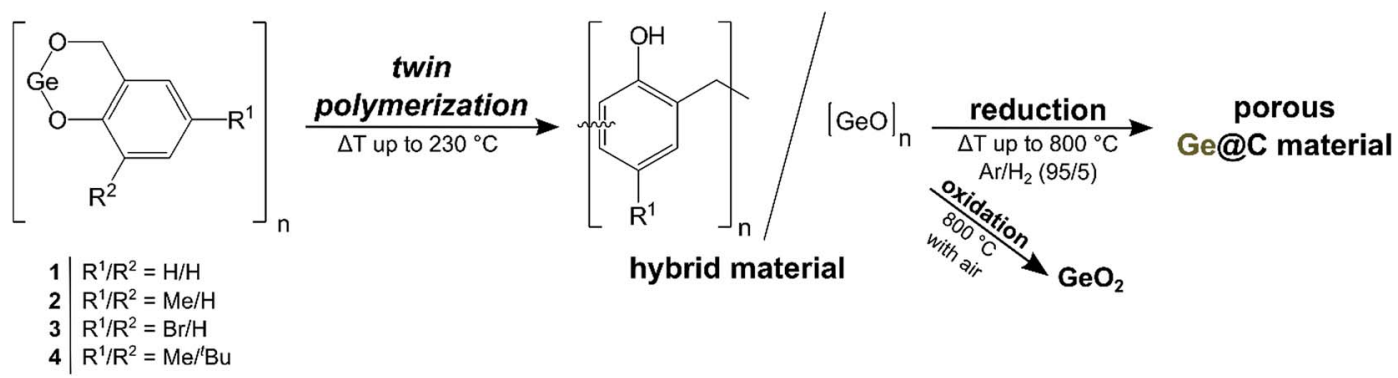

Scheme 1 Illustration of the basic structural motif of the germylenes 1-4 $(n=2-4)$ and the concept for the synthesis of e.g. a porous GeaC material for rechargeable Li-ion batteries starting from 1-3 according to the concept of twin polymerization followed by reduction of the hybrid material.

gave e.g., mesoporous metal oxides, ${ }^{64,65}$ microporous carbon ${ }^{65}$ and mesoporous/microporous nanocomposites such as Sn@C/ $\mathrm{SiO}_{2}{ }^{66}$ We anticipated that porous materials composed of germanium incorporated in a carbon matrix (Ge@C material) are accessible by applying the concept of twin polymerization to the germanium(II) salicyl alcoholates 1-3 (Scheme 1). Ge@C materials are expected to meet requirements such as exhibiting a high capacity and a good cycling stability for anode materials of advanced Li-ion batteries. ${ }^{34}$

Recently, we reported on the synthesis of germanium(II) 2(tert-butyl)-4-methyl-6-(oxidomethyl)phenolate (4), a germanium(II) salicyl alcoholate, which is, however, not suitable for TP. ${ }^{68}$ The tert-butyl and methyl substituents at the aromatic moiety of $\mathbf{4}$ hamper the formation of the phenolic resin resulting in oligomeric structures rather than polymers upon thermal treatment. However, the new germylenes, germanium(II) 2-(oxidomethyl) phenolate (1), germanium(II) 4-methyl-2-(oxidomethyl)phenolate (2) and germanium(II) 4-bromo-2-(oxidomethyl)phenolate (3) are well suited for TP due to the lack of a substituent in the ortho position of their phenolate moieties. Moreover, the substituent in the para positions of their phenolate moieties possess distinguishable steric and electronic features, which is expected to influence their reactivity towards TP as reported for spirocyclic salicyl alcoholates recently. ${ }^{65}$ Characterization including single crystal X-ray diffraction analysis and DFT-D calculations, and studies on their reactivity in TP using differential scanning calorimetry (DSC) are presented. The as-obtained germanium-containing phenolic resin hybrid materials (HM-1HM-3) and the consecutively synthesized $\mathrm{GeO}_{2}$ and $\mathrm{Ge}$ @C materials were characterized by analytical techniques such as solid state NMR spectroscopy (HM-1-HM-3), X-ray photoelectron spectroscopy (XPS), infrared (IR), Raman and energy-dispersive Xray (EDX) spectroscopy, powder X-ray diffraction (PXRD), nitrogen-sorption, measurements transmission electron microscopy (TEM) and CHN analysis. Ge@C materials as obtained starting from germylene $\mathbf{1}$ were tested as anode materials for rechargeable Li-ion batteries and their performance is discussed.

\section{Results and discussion}

\subsection{Synthesis and characterization of germylenes}

The germylenes 1-3 were prepared according to the synthesis protocol of 4 (ref. 68) starting from $\mathrm{Ge}\left[\mathrm{N}\left(\mathrm{SiMe}_{3}\right)_{2}\right]_{2}$ and the respective salicyl alcohol with yields in the range from $64 \%$ to $73 \%$. Poor solubility in non-polar solvents was observed for germylene $\mathbf{3}$, whereas the compounds $\mathbf{1}$ and $\mathbf{2}$ are soluble in all common organic solvents. ${ }^{1} \mathrm{H}$ NMR and ${ }^{1} \mathrm{H}^{13} \mathrm{C}\left\{{ }^{1} \mathrm{H}\right\}$ HSQC NMR spectroscopic analysis of freshly prepared solutions of the germylenes 1-3 in $\mathrm{d}_{8}$-THF at ambient temperature gave broad resonance signals (five signals for $\mathbf{1}$ and 2 in each case, and four signals for 3) indicating a dynamic coordination behavior including oligomeric species, presumably dominated by their monomers. Single crystals suitable for X-ray diffraction analysis were obtained from saturated diethyl ether solutions of the germylenes 1 and 2, from a saturated 1,4-dioxane solution of 3 and from the cloudy reaction mixture (7:4 mixture of $n$ pentane and diethyl ether) containing compound 1 after filtration and slow evaporation of the volatile solvents, respectively. In case of germylene $\mathbf{1}$, a trimer (crystallization from diethyl ether) and a tetramer (crystallization from the reaction mixture) were obtained in the solid state, whereas the compounds 2 and 3 form dimers. Noteworthy, a trimer was previously determined for germylene $\mathbf{4}$ upon crystallization from a saturated diethyl ether solution, whereas in $\mathrm{CDCl}_{3}$ solution an equilibrium between the trimer and the dimer/tetramer was observed. ${ }^{68}$ Thus, the presence of different oligomers of the compounds 1-3 in solution is presumed. DFT-D calculations support this assumption, which is in accordance with the relative formation energies of their oligomers (Scheme 2). The formation of the tetramers was calculated to be energetically slightly favored in comparison with the corresponding trimer formation, whereas the dimers are energetically less favored. However, the small energy differences between the oligomers, especially between their trimers and tetramers, support the assumption that they are in a chemical equilibrium in solution.

Compound 1 crystallizes in the monoclinic space group $P 2_{1} /$ $n$ and forms trimers $(\mathbf{1})_{3}$ in the solid state. The molecular structure is given in Fig. 1 and selected bond lengths and bond angles are presented in the caption of this figure. Details of the structure determination are summarized in Table 3.

The trimer $(\mathbf{1})_{3}$ possesses a similar molecular structure as reported for $(4)_{3} \cdot{ }^{68} \mathrm{~A}$ distorted boat conformation of a sixmembered $-[\mathrm{Ge}-\mathrm{O}-]_{3}$ ring with three-coordinated germanium atoms, one terminal phenolic oxygen atom and two bridging benzylic oxygen atoms, is observed. The germanium oxygen bond lengths $\left[\mathrm{O}_{\mathrm{Aryl}}-\mathrm{Ge}\right.$ bonds: 1.8408(19) $\AA$ A-1.848(2) A , 


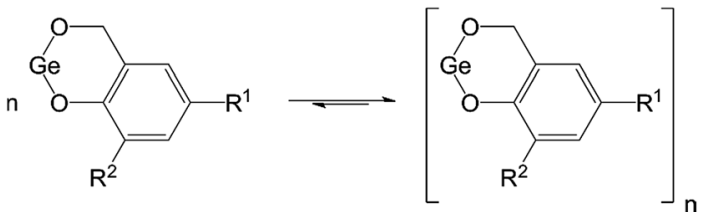

relative energies (referring to the monomer) \begin{tabular}{l|l|l|l|l|l} 
n & $1, R^{1} / R^{2}=H / H$ & $2, R^{1} / R^{2}=M e / H$ & $3, R^{1} / R^{2}=B r / H$ & $4, R^{1 / R^{2}}=M e / B u$ \\
\hline
\end{tabular}

\begin{tabular}{l|l|l|l|l}
\hline 2 & $-51.8^{\mathrm{kJ} / \mathrm{mol}}$ & $-51.6^{\mathrm{kJ}} / \mathrm{mol}$ & $-51.4 \mathrm{~kJ} / \mathrm{mol}$ & $-55.9^{\mathrm{kJ} / \mathrm{mol}}$ \\
3 & $-73.0^{\mathrm{kJ} / \mathrm{mol}}$ & $-74.2^{\mathrm{kJ}} / \mathrm{mol}$ & $-74.3^{\mathrm{kJ} / \mathrm{mol}}$ & $-79.0^{\mathrm{kJ}} / \mathrm{mol}$ \\
4 & $-76.5^{\mathrm{kJ} / \mathrm{mol}}$ & $-76.7^{\mathrm{kJ}} / \mathrm{mol}$ & $-76.4 \mathrm{~kJ} / \mathrm{mol}$ & $-85.5^{\mathrm{kJ}} / \mathrm{mol}$
\end{tabular}

Scheme 2 Illustration of the equilibrium between oligomers of 1-4 in solution (top) and relative energies of the respective oligomers (bottom) calculated on the B3LYP-D3/def2-TZVPP level of theory with regard to the respective monomers.

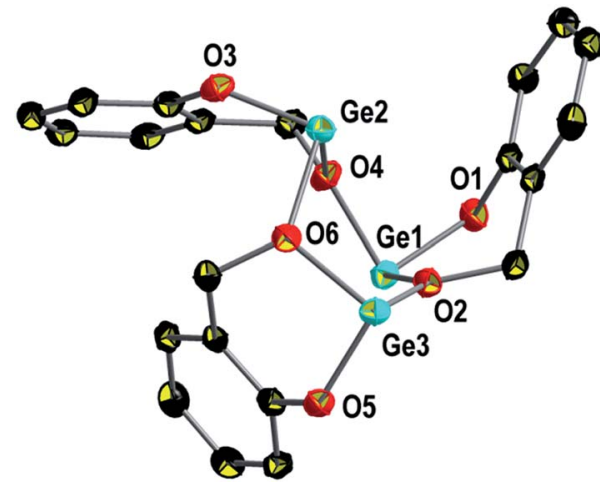

Fig. 1 Molecular structure of $(1)_{3}$ in the solid state. Thermal ellipsoids are drawn with $50 \%$ probability. Hydrogen atoms are omitted for clarity. Selected bond lengths $[\AA]$ and bond angles [ ${ }^{\circ}$ ]: Ge1-O1 1.8408(19), Ge1-O2 1.986(2), Ge1-O4 1.975(2), Ge2-O3 1.848(2), $\mathrm{Ge2}-\mathrm{O} 4$ 1.939(2), Ge2-O6 1.988(2), Ge3-O2 1.988(2), Ge3-O5 1.8447(19), Ge3-O6 1.951(2); Ge1-O4-Ge2 128.28(11), Ge2-O6-Ge3 115.94(10), Ge1-O2-Ge3 132.48(10), O1-Ge1-O2 92.45(9), O1-Ge1$\mathrm{O} 4$ 92.50(9), O2-Ge1-O4 86.80(9), O3-Ge2-O4 91.35(9), O3-Ge2O6 97.57(9), O4-Ge2-O6 88.82(8), O2-Ge3-O5 97.60(8), O2-Ge3O6 86.64(8), O5-Ge3-O6 92.77(9).

$\mathrm{O}_{\text {Alkyl }}-$ Ge bonds: $\left.1.939(2) \AA-1.988(2) \AA\right]$ are in the typical ranges reported for $\mathrm{Ge}-\mathrm{O}$ bonds in compounds with a threefold pyramidal coordination of low valent germanium. ${ }^{69-71}$ The values reported for the germanium oxygen bonds for $(4)_{3}\left[\mathrm{O}_{\mathrm{Aryl}}-\mathrm{Ge}\right.$ bonds: $1.829(2) \AA-1.890(2) \quad \AA, \mathrm{O}_{\mathrm{Alkyl}}-\mathrm{Ge}$ bonds: $1.945(2)$ $\AA-2.044(2) \AA$ ] resemble those in $(1)_{3}$ but are slightly longer [with the exception of Ge3-05: 1.8447(19) $\AA$ for $(1)_{3}$ and 1.829(3) $\AA$ for $(4)_{3}$ ] due to sterically more demanding substituents at the aromatic moieties in $(4)_{3}{ }^{68}$ The shorter Ge1-O2 [1.986(2) $\AA$ ], Ge3-O6 [1.951(2) $\AA]$ and Ge2-O4 [1.939(2) $\AA]$ bonds in comparison to the Ge1-O4 [1.975(2) $\AA]$, Ge3-O2 [1.988(2) $\mathrm{A}]$ and Ge2-O6 [1.988(2) $\AA]$ bond lengths, respectively, indicate secondary bonding of $\mathrm{O} 4 \rightarrow \mathrm{Ge} 1, \mathrm{O} 6 \rightarrow \mathrm{Ge} 2$ and $\mathrm{O} 2 \rightarrow \mathrm{Ge} 3$ stabilizing the low valent species. Additionally, the small O-Ge$\mathrm{O}$ bond angles of the salicylic moieties [O1-Ge1-O2 92.45(9) ${ }^{\circ}$, $\mathrm{O} 3-\mathrm{Ge} 2-\mathrm{O} 491.35(9)^{\circ}$ and $\left.\mathrm{O} 5-\mathrm{Ge} 3-\mathrm{O} 692.77(9)^{\circ}\right]$ and the angles $\angle \mathrm{O} 4-\mathrm{O} 1 \mathrm{Ge} 1 \mathrm{O} 2 \quad 89.337(3)^{\circ}, \quad \angle \mathrm{O} 2-\mathrm{O} 5 \mathrm{Ge} 3 \mathrm{O} 6 \quad 92.840(2)^{\circ}$ and $\angle \mathrm{O} 6-\mathrm{O} 3 \mathrm{Ge} 2 \mathrm{O} 494.408(3)^{\circ}$ are in agreement with low valent germanium atoms possessing a stereochemically active lone pair of electrons and donation of electron density from the bridging benzylic oxygen atoms $(\mathrm{O} 4 \rightarrow \mathrm{Ge} 1, \mathrm{O} 6 \rightarrow \mathrm{Ge} 2$ and $\mathrm{O} 2 \rightarrow \mathrm{Ge} 3)$ into the vacant p-orbitals.

The tetramer $\left[2 \cdot(\mathbf{1})_{4} \cdot n\right.$-pentane $]$ crystallizes in the tetragonal space group $I \overline{4}$ exhibiting two crystallographically independent tetramers, $\alpha-(\mathbf{1})_{4}$ and $\beta-(\mathbf{1})_{4}$, which show similar structural motifs (Fig. S1 $\dagger$ ) and thus only $\alpha-(\mathbf{1})_{4}$ is discussed. The molecular structure of $\alpha-(1)_{4}$ is given in Fig. 2 and selected bond lengths and bond angles are presented in the caption of this figure. Details of the structure determination are summarized in Table 3.

Tetramer $\boldsymbol{\alpha}-(\mathbf{1})_{4}$ consists of four equivalent monomeric building blocks of 1 that can be superimposed as a result of a $S_{4}$ axis (Fig. 2b). The core units of the tetramer shows an eightmembered $-[\mathrm{Ge}-\mathrm{O}-]_{4}$ ring in which the germanium atoms span a distorted tetrahedron (Fig. 2b). The germanium atoms are three-coordinate by one terminal phenolic oxygen atom and two bridging benzylic oxygen atoms. The Ge1-O1 [1.987(3) $⿱ 亠 䒑]$ bond length is shorter than the $\mathrm{Ge} 1-\mathrm{O}^{\prime}$ [2.025(3) $\AA$ ] bond indicating secondary bonding of $\mathrm{O} \rightarrow$ Ge that stabilizes the low valent germanium atoms. The small deviations in the bond lengths and bond angles between $\alpha-(\mathbf{1})_{4}$ and $\beta-(\mathbf{1})_{4}$ may result from crystal packing due to the presence of one molecule $n$-pentane in the unit cell. Please note, when $2 \cdot(\mathbf{1})_{4} \cdot n$-pentane is slowly heated, a reconstruction of the framework to give $(\mathbf{1})_{3}$ and release of the $n$-pentane were observed by temperature-dependent PXRD and thermogravimetric analysis (TGA), respectively (Fig. S2 and S3 $\uparrow$ ). In addition, ${ }^{1} \mathrm{H}$ NMR spectroscopic analysis in $\mathrm{CDCl}_{3}$ at $-60{ }^{\circ} \mathrm{C}$ gave two sets of signals that are assigned to the trimer $(\mathbf{1})_{3}$ and the tetramer $(\mathbf{1})_{4}$. The observation of only one set of signals for the tetramer of $\mathbf{1}$ indicates that $\alpha-(\mathbf{1})_{4}$ and $\beta-(\mathbf{1})_{4}$ relax in their geometries to result in a single tetrameric structure in solution (Fig. S4†).

The dimer $(2)_{2}$ crystallizes in the triclinic space group $P \overline{1}$. The molecular structure of $(2)_{2}$ is depicted in Fig. 3 and selected bond lengths and bond angles are presented in the caption of this figure. Details of the structure determination are summarized in Table 3. A similar structure to $(2)_{2}$ was determined for $(3)_{2}$ (Fig. S5 $\dagger$ ), and therefore, only the molecular structure of $(2)_{2}$ is briefly discussed.

The dimer $(2)_{2}$ exhibits $C_{\mathrm{i}}$ symmetry with a center of inversion located in the plane spanned by the $\mathrm{Ge} 1, \mathrm{O} 2, \mathrm{Ge}^{\prime}$ and $\mathrm{O}^{\prime}{ }^{\prime}$ atoms. The equivalent benzylic oxygen atoms $\mathrm{O} 2$ and $\mathrm{O}^{\prime}$ bridge the germanium atoms, which exhibit a threefold pyramidal coordination. The germanium oxygen bond lengths and bond angles are in agreement with the values determined for $(\mathbf{1})_{3},(\mathbf{1})_{4}$ and $(4)_{3}$ and thus are not further discussed. ${ }^{68}$

\subsection{Twin polymerization}

Thermally induced twin polymerization of the germylenes 1-3 resulted in the formation of germanium-containing phenolic resin hybrid materials. According to the concept of TP the idealized structural motif of the hybrid material is illustrated by eqn (1). 
a)

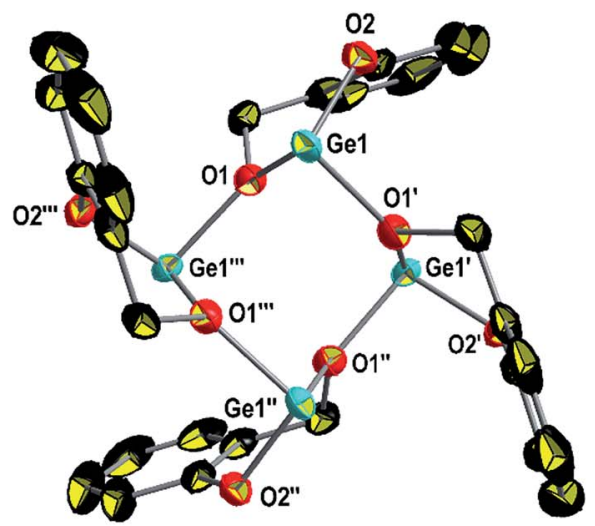

b)
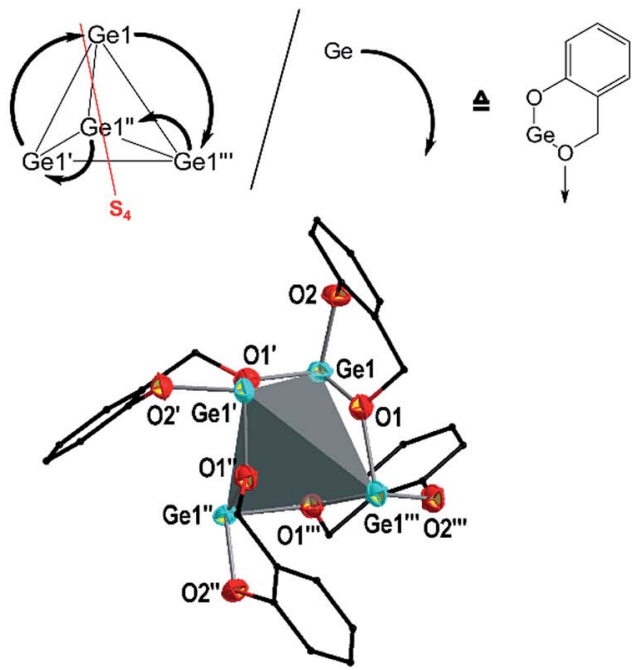

Fig. 2 Molecular structure $\alpha-(1)_{4}(a)$ in the solid state and (b) with salicyl alcoholate moieties depicted in wireframe style and the tetrahedron spanned by the germanium atoms highlighted in grey. The scheme in (b) illustrates the coordination pattern of the bridging benzylic oxygen atoms as indicated by the direction of the arrows. Thermal ellipsoids are drawn with $50 \%$ probability. Hydrogen atoms are omitted for clarity. Selected bond lengths [Å] and bond angles [']: Ge1-O1 1.987(3), Ge1-O2 1.884(3) and Ge1-O1' 2.025(3); Ge1-O1-Ge1' 126.37(16), O1-Ge1-O2 91.36(13), O1-Ge1-O1' 85.29(14) and O2-Ge1-O1' 94.14(12). Symmetry transformations used to generate equivalent atoms: ${ }^{\prime}=x-0.5,-y+$ $1.5,-z+0.5 ;^{\prime \prime}=-x+2,-y+1, z ;{ }^{\prime \prime \prime}=-x+1.5, y+0.5,-z+0.5$.

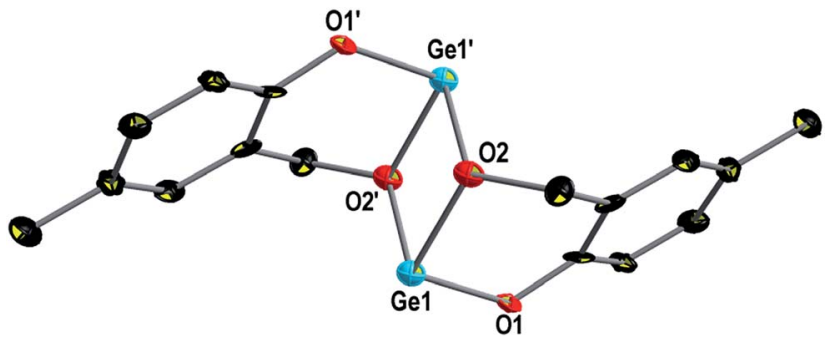

Fig. 3 Molecular structure of (2) $)_{2}$ in the solid state. Thermal ellipsoids are drawn with $50 \%$ probability. Hydrogen atoms are omitted for clarity. Selected bond lengths $[\AA \AA]$ and bond angles $\left[{ }^{\circ}\right]$ : Ge1-01 1.862(7), $\mathrm{Ge1}-\mathrm{O} 2$ 1.986(6), Ge1-O2' 1.966(7); Ge1-O2-Ge1' 104.6(3), O1Ge1-O2 91.6(3), O1-Ge1-O2' 94.9(3), O2-Ge1-O2' 75.4(3). Symmetry transformations used to generate equivalent atoms: ${ }^{\prime}=-x$, $-y+1,-z+1$.

The molecular structures of the compounds 2 and 3, exhibiting a substituent in para position to the phenolic oxygen atom, favor the ortho/ortho' connectivity of the bridging methylene groups interconnecting the benzene rings in the phenolic resin as obtained after polymerization. By contrast, precursor 1 allows additional ortho/para' connectivity. In general, the phenolic resins that were prepared by twin polymerization show a high degree of cross linkages of the bridging methylene groups and are insoluble. It is noteworthy that our attempts to obtain polymeric hybrid materials by proton induced twin polymerization as reported for other metal salicyl alcoholates $(\mathrm{M}=\mathrm{Si}, \mathrm{Ge}$ and $\mathrm{Sn})^{\mathbf{6 4 , 6 5 , 6 7}}$ failed. However, thermally induced twin polymerization is feasible as it is outlined in the following section.

2.2.1 Studies on the reactivity. Studies on the reactivity of the compounds 1-3 regarding the process of thermally induced TP were performed by differential scanning calorimetry (DSC) measurements up to $300{ }^{\circ} \mathrm{C}$. The thermograms starting from amorphous materials are depicted in Fig. 4.

The compounds 1-3 do not melt and the DSC curves show exothermic processes, which are assigned to thermally induced TP. The onset temperatures are $102{ }^{\circ} \mathrm{C}(1), 163{ }^{\circ} \mathrm{C}(2)$ and $151{ }^{\circ} \mathrm{C}$ (3). Two distinguishable minima at $110{ }^{\circ} \mathrm{C}$ and $145{ }^{\circ} \mathrm{C}$ for $\mathbf{1}$, $183{ }^{\circ} \mathrm{C}$ and $194{ }^{\circ} \mathrm{C}$ for 2 , and $161^{\circ} \mathrm{C}$ and $200{ }^{\circ} \mathrm{C}$ for 3 indicate that different formation processes take place at specific

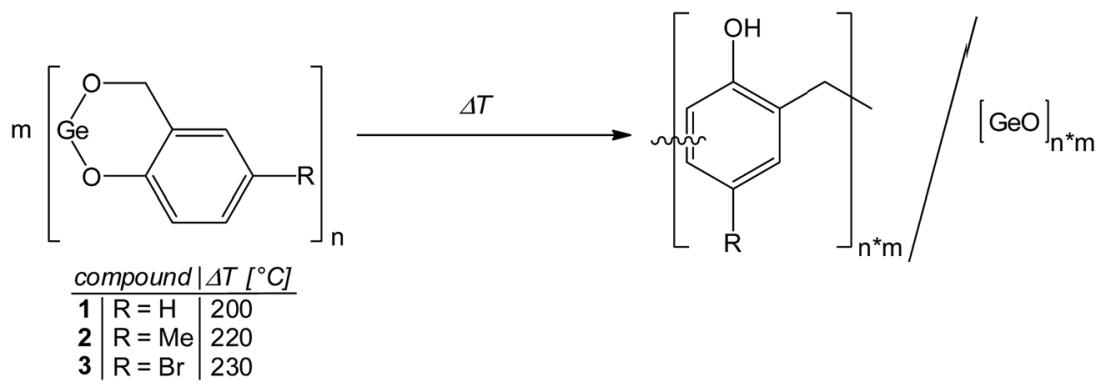




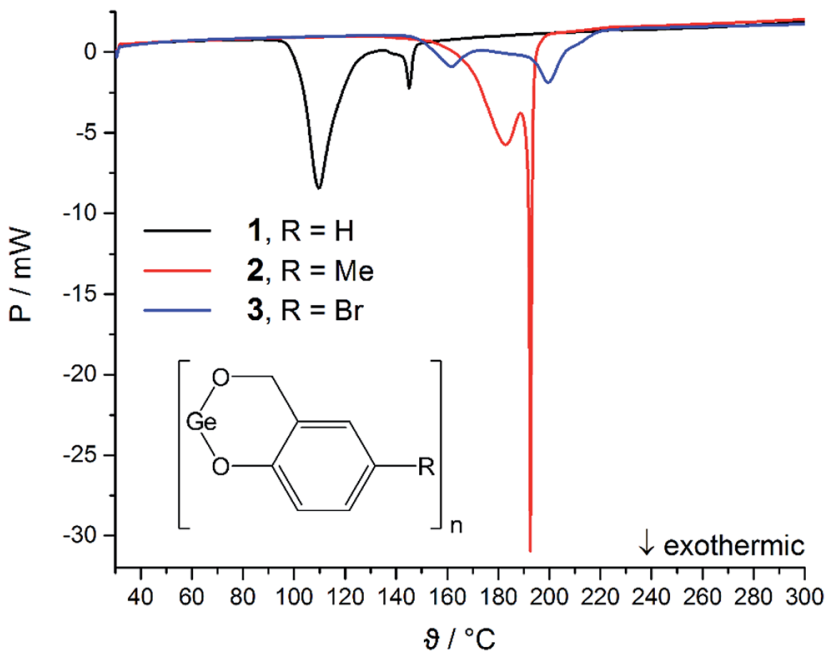

Fig. 4 Differential scanning calorimetry of the amorphous materials of the germylenes 1 (black curve), 2 (red curve) and 3 (blue curve); heating

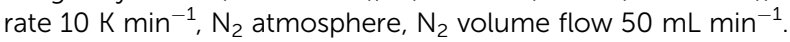

temperatures during the polymerization processes e.g., formation of the phenolic resin and/or condensation to give the final germanium-containing resin. The observation of two minima in all DSC experiments indicate that the polymerization follows similar reaction processes for 1-3, but the compounds show a different reactivity. However, the order of the onset temperatures does not follow the electronic and steric features of the substituents as was expected based on previous reports for spirocyclic silicon salicyl alcoholates. ${ }^{65}$ Thus, we conclude that the nature of the substituents in 1-3 plays a minor role for the initiation process here. This assumption is further supported by comparison of the onset temperatures of the polymerization process for amorphous $1\left(102{ }^{\circ} \mathrm{C}\right)$ and the crystalline materials $(\mathbf{1})_{3}\left(142{ }^{\circ} \mathrm{C}\right)$ and $2 \cdot(\mathbf{1})_{4} \cdot n$-pentane $\left(119{ }^{\circ} \mathrm{C}\right)$ (Fig. 5).

The different onset temperatures indicate that the initiation of the polymerization process depends on structural parameters of the germylenes e.g., structure of the oligomer and/or crystal packing effects. The crystalline forms of germylene $\mathbf{1}$ gave higher onset temperatures and narrower temperature ranges $\left(\Delta 15{ }^{\circ} \mathrm{C}\right)$ for the exothermic processes than observed for the amorphous material. The exothermic processes gave a $\frac{\mathrm{d} Q}{\mathrm{~d} m}$ value of $-345 \mathrm{~J} \mathrm{~g}^{-1}$ for amorphous $\mathbf{1},-377 \mathrm{~J} \mathrm{~g}^{-1}$ for crystalline $(\mathbf{1})_{3}$ and $-340 \mathrm{~J} \mathrm{~g}^{-1}$ for crystalline $2 \cdot(\mathbf{1})_{4} \cdot n$-pentane. Thus, the ascalculated molar reaction enthalpies $(\Delta H)$ that are referred to one monomeric unit of $1\left(M=194.73 \mathrm{~g} \mathrm{~mol}^{-1}\right)$ are $-67 \mathrm{~kJ} \mathrm{~mol}^{-1}$ for amorphous $\mathbf{1},-73 \mathrm{~kJ} \mathrm{~mol}^{-1}$ for crystalline $(\mathbf{1})_{3}$ and $-66 \mathrm{~kJ} \mathrm{~mol}^{-1}$ for crystalline $2 \cdot(\mathbf{1})_{4} \cdot n$-pentane. As the $\frac{\mathrm{d} Q}{\mathrm{~d} m}$ values and as a consequence the molar reaction enthalpies $(\Delta H)$ are comparable for the amorphous and the crystalline materials of $\mathbf{1}$, the reaction energies do not rely on the structures of the precursors. It is noteworthy that the DSC curve of $2 \cdot(\mathbf{1})_{4}$. $n$-pentane exhibits a second minimum at $146{ }^{\circ} \mathrm{C}$ as it is also observed for amorphous $1\left(145{ }^{\circ} \mathrm{C}\right)$. These minima are close to the single minimum detected for the twin polymerization of $(\mathbf{1})_{3}$

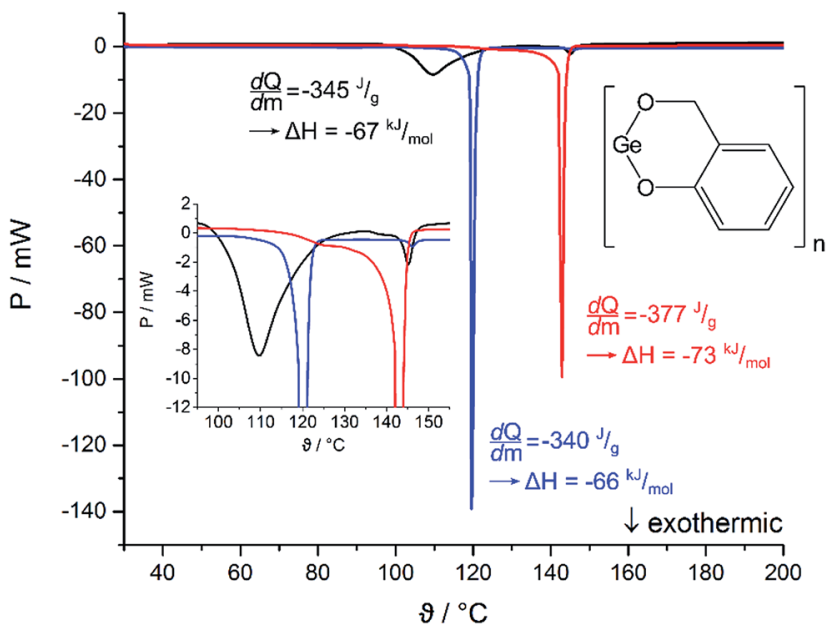

Fig. 5 Differential scanning calorimetry of amorphous 1 (black curve), crystals of $(1)_{3}$ (red curve) and crystals of $2 \cdot(1)_{4} \cdot n$-pentane (blue curve); heating rate $10 \mathrm{~K} \mathrm{~min}^{-1}, \mathrm{~N}_{2}$ atmosphere, $\mathrm{N}_{2}$ volume flow $50 \mathrm{~mL} \mathrm{~min}^{-1}$. The inlet magnifies the range between $95^{\circ} \mathrm{C}$ and $155^{\circ} \mathrm{C}$. The determined $\frac{\mathrm{d} Q}{\mathrm{~d} m}$ values and the as-calculated molar reaction enthalpies $(\Delta H)$ that are referred to one monomeric unit of 1 of the exothermic processes are depicted in black for amorphous 1 , red for crystals of $(1)_{3}$ and blue for crystals of $2 \cdot(1)_{4} \cdot n$-pentane.

$\left(143{ }^{\circ} \mathrm{C}\right)$ indicating that at least some formation processes in order to form the hybrid material e.g., formation of the germanium oxide, take place at higher temperatures. We conclude that amorphous materials possess smaller reaction barriers for the initiation process of thermally induced twin polymerization. The initiation of $\mathrm{TP}$ for the crystalline materials is aggravated presumably due to crystal packing. However, as the polymerization process is initiated, the thermally induced TP of the germylenes is facilitated by a pre-organized arrangement of the precursors considering the narrow temperature ranges of the polymerization process for the crystalline forms of 1 .

2.2.2 Characterization of the hybrid materials obtained by thermally induced twin polymerization. Thermally induced twin polymerization of 1-3 was carried out by bulk phase experiments under inert atmosphere. Polymerization temperatures of $200-230{ }^{\circ} \mathrm{C}$ were chosen according to the results of the DSC measurements of the germylenes 1-3. The as-obtained germanium-containing phenolic resin hybrid materials were characterized by ${ }^{13} \mathrm{C}\left\{{ }^{1} \mathrm{H}\right\}$ cross polarization magic angle spinning (CP-MAS) NMR and IR spectroscopy, PXRD, CHN analysis, XPS (exemplarily carried out for HM-1) and EDX spectroscopy. A summary of the polymerization temperatures, the product identities and the yields of the as-obtained hybrid materials is given in Table 1. Fig. 6 depicts the ${ }^{13} \mathrm{C}\left\{{ }^{1} \mathrm{H}\right\}$ CP-MAS NMR spectra of these materials.

All expected signals for the phenolic resin of the hybrid materials HM-1-HM-3 were observed with typical chemical shifts as reported for hybrid materials obtained by thermally induced TP. ${ }^{55,65}$ The broad resonance signals with chemical shifts of $\delta=20-30 \mathrm{ppm}$ and the resonance signals between $\delta=$ 
Table 1 Polymerization temperatures, product identities and yields of the germanium-containing phenolic resin hybrid materials as obtained by thermally induced TP of $1-3$

\begin{tabular}{|c|c|c|c|c|}
\hline Germylene & $\mathrm{R}$ & Polymerization temperature $\left[{ }^{\circ} \mathrm{C}\right]$ & Product & Yield $^{a}[\%]$ \\
\hline 1 & $\mathrm{H}$ & 200 & HM-1, pale yellow monolith & 92 \\
\hline 2 & $\mathrm{Me}$ & 220 & HM-2, yellow monolith & 97 \\
\hline
\end{tabular}

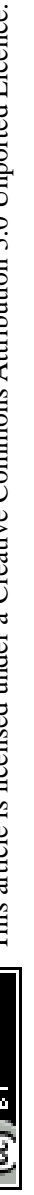

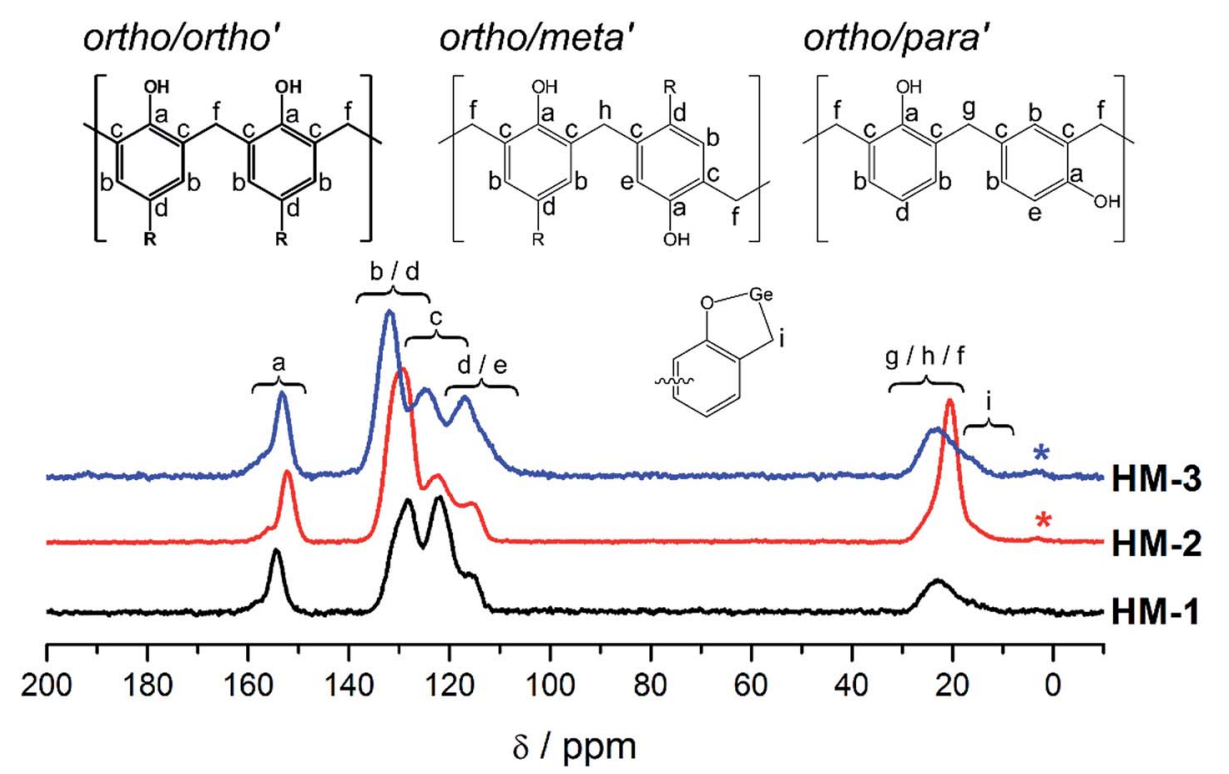

Fig. $6{ }^{13} \mathrm{C}\left\{{ }^{1} \mathrm{H}\right\}$ CP-MAS NMR spectra of the germanium-containing phenolic resin hybrid materials as obtained by thermally induced twin polymerization of $1-3$. The spectra of $\mathrm{HM}-1, \mathrm{HM}-2$ and $\mathrm{HM}-3$ are depicted as black, red and blue lines, respectively. The asterisks * mark spinning side bands. Assignment of the resonance signals is given for the assigned connectivity patterns of the bridging methylene groups (ortho/para' only for $\mathrm{HM}-1$ ).

110-120 ppm (unsubstituted ortho carbons: $\delta=113-117 \mathrm{ppm}$ (ref. 72)) indicate the presence of nonequivalent bridging methylene groups in the phenolic resin for all hybrid materials. ${ }^{72-74}$ Nevertheless, the resonance signals assigned to the bridging methylene groups $(\delta=20-30 \mathrm{ppm})$ exhibit the most intense resonance signals centered at $\delta=23 \mathrm{ppm}$ indicating that an ortho/ortho' connectivity of the bridging methylene groups is prevalent in the phenolic resin even for HM-1. These values match with reference data reported for ortho/ortho' bridging methylene carbons of phenol-formaldehyde resins $(\delta$ $=20-27 \mathrm{ppm}){ }^{73}$ In addition, a trend for the content of unsymmetrical connectivity patterns of the bridging methylene groups with respect to electronic and steric features of the substituents is not observed, which is in contrast to our studies of the phenolic resin-silica hybrid materials obtained by thermally induced TP of spirocyclic silicon salicyl alcoholates. ${ }^{65}$ The latter and the prevalent ortho/ortho' connectivity of the bridging methylene groups indicate that the connectivity motif of the phenolic resin in the hybrid materials is only marginally influenced by the nature of the substituents at the aromatic moieties of the germylenes. It is noteworthy that the resonance signals, which are assigned to the bridging methylene groups, exhibit shoulders with chemical shifts centered at $\delta=16 \mathrm{ppm}$ in all ${ }^{13} \mathrm{C}$ $\left\{{ }^{1} \mathrm{H}\right\}$ CP-MAS NMR spectra. This observation is assigned to the presence of small amounts of $\mathrm{Ge}-\mathrm{CH}_{2}$ connectivity within the hybrid materials (Fig. S6 $\dagger$ ). The latter is a result of an oxidative insertion reaction of the germylenes as reported previously for compound 4, which slowly converts into 2,4,6,8-tetra-(3tert-butyl-5-methyl-2-oxidophenyl)-methanide-1,3,5,7,2,4,6,8tetraoxidogermocane (5) in solution (Fig. S6 $\dagger$ ) ${ }^{68}$ Compound 5 serves as a model compound for XPS analysis that was exemplarily carried out for $\mathbf{H M - 1}$ due to its $\mathrm{Ge}-\mathrm{CH}_{2}$ groups. The XPS data indicate that the germanium atoms in HM-1 exhibit a similar chemical environment as it was determined for $\mathbf{5}$ (Fig. S7 $\dagger$ ). However, the XPS data are also consistent with data reported for germanium oxides. ${ }^{75-85}$ Thus the XPS data do not allow to differentiate between the presence of $\mathrm{Ge}-\mathrm{CH}_{2}$ connectivity and germanium oxides within HM-1. However, in accordance with the ${ }^{13} \mathrm{C}\left\{{ }^{1} \mathrm{H}\right\}$ CP-MAS NMR data, we suggest that thermally induced TP of the germylenes provides hybrid materials consisting of germanium oxide incorporated in a phenolic resins, which contains small portions of $\mathrm{Ge}-\mathrm{CH}_{2}$ connectivity. 
Typical IR absorption bands for $\nu(\mathrm{O}-\mathrm{H})\left(3600-3200 \mathrm{~cm}^{-1}\right)$, $\nu(\mathrm{C}=\mathrm{C})\left(1600-1400 \mathrm{~cm}^{-1}\right), \nu(\mathrm{C}-\mathrm{O})\left(1250-1200 \mathrm{~cm}^{-1}\right)$, aromatic backbone vibrational modes $\left(850-700 \mathrm{~cm}^{-1}\right)$ and $\mathrm{Ge}-\mathrm{O}$ vibrational modes $\left(430-650 \mathrm{~cm}^{-1}\right)$ were observed in the FT-IR spectra of all hybrid materials (Fig. S8 $\dagger$ ). An additional absorption band maximum at $1096 \mathrm{~cm}^{-1}$ was observed in the IR spectrum of HM3 , which is assigned to the $\mathrm{C}-\mathrm{Br}$ stretching vibrational mode. CHN analyses revealed carbon contents of the hybrid materials that are slightly lower than the values $(\Delta C<1.1 \%)$ calculated for complete conversions of the germylenes. The latter is in agreement with the determined minor weight losses (Fig. S3†) during the polymerization processes. However, the rather small deviations in the determined carbon and hydrogen contents in comparison with their calculated values indicate a high amount of conversion of the germylenes into the hybrid materials. This is further supported by EDX analysis and the high yields as obtained for the hybrid materials after the work up procedures.

\subsection{Synthesis and characterization of porous materials}

Conversion of phenolic resin-silica hybrid materials obtained by TP of spirocyclic silicon salicyl alcoholates into microporous carbon and into mesoporous silica was reported by us recently. ${ }^{65}$ Variations of the molecular structure of the precursors $e . g$., different substituents at the aromatic moieties were shown to affect the properties of the porous materials. ${ }^{65}$ Expecting qualitatively similar results, we carried out the conversion reactions of the germanium-containing phenolic resin hybrid materials (HM-1-HM-3) under reductive and oxidative conditions in order to obtain porous materials consisting of germanium incorporated in a carbon matrix (Ge@C) and porous $\mathrm{GeO}_{2}$, respectively (Scheme 1). The product identities of the as-obtained $\mathrm{Ge} @ \mathrm{C}$ and $\mathrm{GeO}_{2}$ materials, their BET surface areas and in case of the Ge@C composites the pore volumes determined by nitrogen adsorption measurements in addition with their germanium content are summarized in Table 2.

The as-prepared Ge@C materials exhibit large BET surface areas with $\mathbf{C}-3\left(418 \mathrm{~m}^{2} \mathrm{~g}^{-1}\right)$ offering the largest value. The adsorption isotherms of the $\mathrm{Ge}(\mathrm{C}$ composites are assigned to type I isotherms showing hysteresis loops (Fig. S9†), which may result from bottleneck pores. Analysis of the adsorption isotherms using QSDFT gave $14.9 \%$ (C-2), 25.1\% (C-1a), 34.5\% (C-1b) and 46.7\% (C-3) micropore contents (Fig. S10†). CHN analyses gave carbon contents of $32.66 \%$ (C-1a), 34.41\% (C-1b), $31.58 \%(\mathbf{C}-2)$ and $60.89 \%$ (C-3). In addition, EDX spectroscopy revealed germanium contents of $(46.5 \pm 2.8) \%(\mathbf{C}-1 \mathrm{a}),(39.8 \pm$ $2.4) \%(\mathbf{C}-1 \mathbf{b}),(36.6 \pm 2.0) \%(\mathbf{C}-2)$ and $(26.5 \pm 1.6) \%(\mathbf{C}-3)$. Bromine was not detected by EDX analysis of C-3. The materials C-1a, C-1b and C-2 exhibit low carbon but high germanium contents, whereas a low germanium and a high carbon content were determined for $\mathbf{C}-\mathbf{3}$. The mass losses during the synthesis of C-1a, C-1b and C-2 were about 50\%, whereas $68 \%$ was observed for C-3. The latter, in addition with the high carbon value, low germanium and lacking bromine content as determined for $\mathbf{C}-\mathbf{3}$, indicate that large amounts of germanium and almost all bromine were removed during the synthesis of $\mathbf{C}-\mathbf{3}$ resulting in a material exhibiting a much higher carbon content (C: $60.89 \%$ ) as initially present in the starting material HM-3 (C: $30.10 \%$ ) or germylene 3 (C: $30.40 \%$ ). As carbon is mainly the porous component of the $\mathrm{Ge} @ \mathrm{C}$ materials, the higher specific surface-to-mass ratio of C-3 results from larger proportions of carbonized material in addition with the higher micropore content that may result from decomposition processes (Fig. S3 and S11 $\dagger$ ) causing the removal of all bromine and some germanium. Raman spectroscopy using a confocal micro Raman system revealed for Ge@C areas that exhibit either high germanium but low carbon or high carbon but low germanium contents (Fig. S12†). The latter is indicative that phase separation between germanium and carbon on the $\mu \mathrm{m}$-scale occurred during the synthesis of the Ge@C composites under reductive conditions, which was confirmed by scanning electron microscopy in combination with EDX mapping (SEM/EDX) (Fig. S13 $\dagger$ ). However, PXRD analyses revealed that the Ge@C composites exhibit crystallites with average primary particle size of $(51 \pm 6) \mathrm{nm}$ (C-1a), (13 \pm 1$) \mathrm{nm}$ (C-1b), (39 \pm 3$) \mathrm{nm}$ (C-2) and $(38 \pm 3) \mathrm{nm}(\mathbf{C}-3)$ (Fig. S14†). TEM images exemplarily recorded for $\mathbf{C - 1 a}$ and $\mathbf{C - 1 \mathbf { b }}$ of selected carbon-rich areas revealed the presence of nanoscaled areas $(<10 \mathrm{~nm})$ consisting of crystalline germanium (Fig. S15†). Notably, smaller crystallites were obtained at $600^{\circ} \mathrm{C}[(13 \pm 1) \mathrm{nm}$ for $\mathbf{C}-\mathbf{1 b}]$ as compared

Table 2 Summary of the product identities of the as-obtained $\mathrm{GeaC}$ and $\mathrm{GeO}_{2}$ materials, their single point BET surface areas and in case of the $\mathrm{GeaC}$ materials the pore volumes determined by nitrogen adsorption measurements in addition with their germanium content

Ge@C materials obtained under reductive conditions ${ }^{a}$

\begin{tabular}{|c|c|c|c|c|c|c|c|}
\hline $\begin{array}{l}\text { Starting } \\
\text { material }\end{array}$ & Product & $\begin{array}{l}\text { BET surface area } \\
{\left[\mathrm{m}^{2} \mathrm{~g}^{-1}\right]}\end{array}$ & $\begin{array}{l}\text { Pore volume }^{d} \\
{\left[\mathrm{~cm}^{3} \mathrm{~g}^{-1}\right]} \\
(\text { micropore content }[\%])\end{array}$ & $\begin{array}{l}\text { Germanium } \\
\text { content }^{e}[\%]\end{array}$ & $\begin{array}{l}\text { Starting } \\
\text { material }\end{array}$ & Product & $\begin{array}{l}\text { BET surface area } \\
{\left[\mathrm{m}^{2} \mathrm{~g}^{-1}\right]}\end{array}$ \\
\hline HM-1 & C-1b & 238 & $0.165(34.5)$ & $39.8 \pm 2.4$ & HM-2 & $0 x-2$ & 9 \\
\hline HM-2 & C-2 & 244 & $0.236(14.9)$ & $36.6 \pm 2.0$ & HM-3 & Ox-3 & 20 \\
\hline HM-3 & $\mathrm{C}-3$ & 418 & $0.273(46.7)$ & $26.5 \pm 1.6$ & & & \\
\hline
\end{tabular}

${ }^{a}$ At $800{ }^{\circ} \mathrm{C}\left(600{ }^{\circ} \mathrm{C}\right.$ for $\left.\mathrm{C}-1 \mathrm{~b}\right)$ for $3 \mathrm{~h}$ under $\mathrm{Ar} / \mathrm{H}_{2}$ flux $\left(95 / 5,20 \mathrm{~L} \mathrm{~h}^{-1}\right)$, heating rate $10 \mathrm{~K} \mathrm{~min}^{-1} \cdot{ }^{b}$ At $800{ }^{\circ} \mathrm{C}$ for $3 \mathrm{~h}$ under air flux $\left(200 \mathrm{~L} \mathrm{~h}{ }^{-1}\right)$, heating rate $10 \mathrm{~K} \mathrm{~min}^{-1} .{ }^{c} p / p_{0}=0.150 \pm 0.002 .{ }^{d}$ Determined by the QSDFT model for slit and cylindrical pores using the adsorption branch of the isotherms. ${ }^{e}$ Determined by EDX spectroscopy. 
Table 3 Crystallographic and experimental data of the single crystal X-ray diffraction analyses of $(1)_{3}, 2 \cdot(1)_{4} \cdot n$-pentane, $(2)_{2}$ and $(3)_{2} \cdot 1,4$-dioxane

\begin{tabular}{|c|c|c|c|c|}
\hline Compound & $(\mathbf{1})_{3}$ & $2 \cdot(\mathbf{1})_{4} \cdot n$-pentane & $(2)_{2}$ & $(3)_{2} \cdot 1,4$-dioxane \\
\hline Formula & $\mathrm{C}_{21} \mathrm{H}_{18} \mathrm{Ge}_{3} \mathrm{O}_{6}$ & $\mathrm{C}_{61} \mathrm{H}_{60} \mathrm{Ge}_{8} \mathrm{O}_{16}$ & $\mathrm{C}_{16} \mathrm{H}_{16} \mathrm{Ge}_{2} \mathrm{O}_{4}$ & $\mathrm{C}_{18} \mathrm{H}_{18} \mathrm{Br}_{2} \mathrm{Ge}_{2} \mathrm{O}_{6}$ \\
\hline Molecular mass & $584.12 \mathrm{~g} \mathrm{~mol}^{-1}$ & $1629.81 \mathrm{~g} \mathrm{~mol}^{-1}$ & $417.47 \mathrm{~g} \mathrm{~mol}^{-1}$ & $635.32 \mathrm{~g} \mathrm{~mol}^{-1}$ \\
\hline Temperature & $100 \mathrm{~K}$ & $110 \mathrm{~K}$ & $110 \mathrm{~K}$ & $100 \mathrm{~K}$ \\
\hline Wavelength & $1.54184 \AA$ & $0.71073 \AA$ & $0.71073 \AA$ & $0.71073 \AA$ \\
\hline Crystal system & Monoclinic & Tetragonal & Triclinic & Monoclinic \\
\hline Space group & $P 2_{1} / n$ & $I \overline{4}$ & $P \overline{1}$ & $P 2_{1} / c$ \\
\hline Crystal size & $0.2 \times 0.2 \times 0.16 \mathrm{~mm}$ & $0.20 \times 0.20 \times 0.18 \mathrm{~mm}$ & $\begin{array}{l}0.4974 \times 0.4881 \times 0.0897 \\
\mathrm{~mm}\end{array}$ & $0.34 \times 0.06 \times 0.04 \mathrm{~mm}$ \\
\hline$a$ & $11.5755(3) \AA$ & $14.4998(3) \AA$ & $5.0400(8) \AA$ & $9.1184(6) \AA$ \\
\hline$b$ & $16.1191(10) \AA$ & $14.4998(3) \AA$ & $5.7142(6) \AA$ & $5.8156(4) \AA$ \\
\hline$c$ & $11.8463(4) \AA$ & $14.6335(6) \AA$ & $13.393(2) \AA$ & $18.7848(10) \AA$ \\
\hline$\alpha$ & $90^{\circ}$ & $90^{\circ}$ & $78.607(11)^{\circ}$ & $90^{\circ}$ \\
\hline$\beta$ & $110.168(4)^{\circ}$ & $90^{\circ}$ & $81.131(14)^{\circ}$ & $91.848(5)^{\circ}$ \\
\hline$\gamma$ & $90^{\circ}$ & $90^{\circ}$ & $89.160(11)^{\circ}$ & $90^{\circ}$ \\
\hline$V$ & $2074.83(16) \AA^{3}$ & $3076.61(18) \AA^{3}$ & $373.54(9) \AA^{3}$ & $995.62(11) \AA^{3}$ \\
\hline$Z$ & 4 & 2 & 1 & 2 \\
\hline Density calculated & $1.870 \mathrm{mg} \mathrm{m}^{-3}$ & $1.759 \mathrm{mg} \mathrm{m}^{-3}$ & $1.856 \mathrm{mg} \mathrm{m}^{-3}$ & $2.119 \mathrm{mg} \mathrm{m}^{-3}$ \\
\hline$\mu\left[\mathrm{mm}^{-1}\right]$ & $5.455 \mathrm{~mm}^{-1}$ & $3.920 \mathrm{~mm}^{-1}$ & $4.019 \mathrm{~mm}^{-1}$ & $7.066 \mathrm{~mm}^{-1}$ \\
\hline$F(000)$ & 1152 & 1620 & 208 & 616 \\
\hline $\begin{array}{l}\text { Theta range for data } \\
\text { collection }\end{array}$ & 4.83 to $63.94^{\circ}$ & 3.421 to $24.977^{\circ}$ & 3.141 to $24.991^{\circ}$ & 3.67 to $24.99^{\circ}$ \\
\hline \multirow[t]{3}{*}{ Index ranges } & $-12 \leq h \leq 13$ & $-17 \leq h \leq 16$ & $-5 \leq h \leq 5$ & $-10 \leq h \leq 10$ \\
\hline & $-17 \leq k \leq 18$ & $-17 \leq k \leq 12$ & $-6 \leq k \leq 6$ & $-6 \leq k \leq 6$ \\
\hline & $-13 \leq l \leq 8$ & $-13 \leq l \leq 17$ & $-15 \leq l \leq 15$ & $-13 \leq l \leq 22$ \\
\hline Reflections collected & 6394 & 5657 & 1656 & 3242 \\
\hline Independent reflections & $3365[R($ int. $)=0.0260]$ & $2651[R($ int. $)=0.0186]$ & $1656[R($ int. $)=0.0612]$ & $1738[R($ int. $)=0.0471]$ \\
\hline Data & 3365 & 2651 & 1656 & 1738 \\
\hline Goodness-of-fit on $F^{2}$ & 1.031 & 1.041 & 1.104 & 0.916 \\
\hline $\begin{array}{l}\text { Final } R \text { indices }[I>2 \sigma(l)], \mathrm{w} R_{2} \\
\left(F^{2}\right) \text { (all data) }\end{array}$ & $R_{1}=0.0345, \mathrm{w} R_{2}=0.0930$ & $R_{1}=0.0219, \mathrm{w} R_{2}=0.0463$ & $R_{1}=0.0597, \mathrm{w} R_{2}=0.1798$ & $R_{1}=0.0398, \mathrm{w} R_{2}=0.0927$ \\
\hline Largest diff. peak and hole & 0.632 and $-0.531{\mathrm{e} \AA^{-3}}^{-3}$ & 0.301 and $-0.265{\mathrm{e} \AA^{-3}}^{-3}$ & 1.495 and $-1.544{\mathrm{e} \AA^{-3}}^{-3}$ & 1.108 and $-0.649{\mathrm{e} \AA^{-3}}^{-3}$ \\
\hline
\end{tabular}

to $800{ }^{\circ} \mathrm{C}[(51 \pm 6) \mathrm{nm}$ for $\mathbf{C}-1 \mathrm{a}]$, while the BET surface area does not differ significantly.

The as-prepared $\mathrm{GeO}_{2}$ samples exhibit low BET surface areas, which is indicative for a non-porous material. This is further supported by the adsorption isotherms that were assigned to type II isotherms, which is typical for non-porous and/or macroporous materials (Fig. S9†). The isotherms show pronounced hysteresis down to $p / p_{0}<0.05$, which may result from hampering adsorption and/or hindered desorption of nitrogen due to interactions between the adsorbate and the adsorbent. PXRD analysis and Raman spectroscopy revealed the formation of hexagonal $\mathrm{GeO}_{2}$ for all oxidized materials. However, minor portions of tetragonal $\mathrm{GeO}_{2}$ were also detected for $\mathbf{O x}-\mathbf{1}$ and $\mathbf{O x}-\mathbf{2}$ (Fig. S12 and S14†).

In conclusion, porous $\mathrm{Ge} @ \mathrm{C}$ composites and non-porous $\mathrm{GeO}_{2}$ were obtained following the synthesis concept of TP (Scheme 1). The properties of the as-obtained $\mathrm{Ge} @ \mathrm{C}$ and $\mathrm{GeO}_{2}$ materials is only marginally influenced by the molecular structure of the precursors with the exception that bromine within the hybrid material (HM-3) results in larger loss of germanium by removal of all bromine during the synthesis of the Ge@C material (C-3). This results in higher carbon contents and larger BET surface area for Ge@C composites (C-3 vs. C-1/C2). The finally obtained non-porous $\mathrm{GeO}_{2}$ materials indicate that the proposed germanium oxide networks within the hybrid materials [eqn (1)] is not stable with respect to further conversion processes. However, the formation of the as-obtained microporous Ge@C composites containing germanium nanocrystals indicates that the hybrid materials consisting of phenolic-resin and germanium oxide as dominant germanium species exhibit indeed phase nanodomains.

\subsection{Electrochemical measurements}

In order to provide a proof of principle, the Ge@C materials $\mathbf{C}$ 1a and $\mathbf{C - 1 b}$ were tested as potential anode material for rechargeable Li-ion batteries. Electrodes were prepared by mixing the respective Ge@C sample with carbon black $(\mathrm{CB})$ and carboxymethyl cellulose (CMC) with the mass ratio of $8: 1: 1$ using a planetary ball-mill. Electrochemical tests were carried out in Li-ion half cells using $1 \mathrm{M} \mathrm{LiPF}_{6}$ in a mixture $(1: 1$ by weight) of ethylene carbonate (EC) and dimethyl carbonate (DMC) as electrolyte. Fluoroethylene carbonate (FEC) was used as electrolyte additive to improve cycling stability. ${ }^{43}$ The results of the electrochemical measurements for C1-a and C1-b are shown in Fig. 7. Cells were cycled in the potential range of $0.005-1.0 \mathrm{~V}$ using a current of $346 \mathrm{~mA} \mathrm{~g}^{-1}$ or $1384 \mathrm{~mA} \mathrm{~g}^{-1}$ respectively.

For the first discharge cycle high irreversible capacities are obtained due to the formation of the solid electrolyte interface and the reduction of surface oxides according to $\mathrm{GeO}_{2}+4 \mathrm{Li}^{+}+$ 
a)

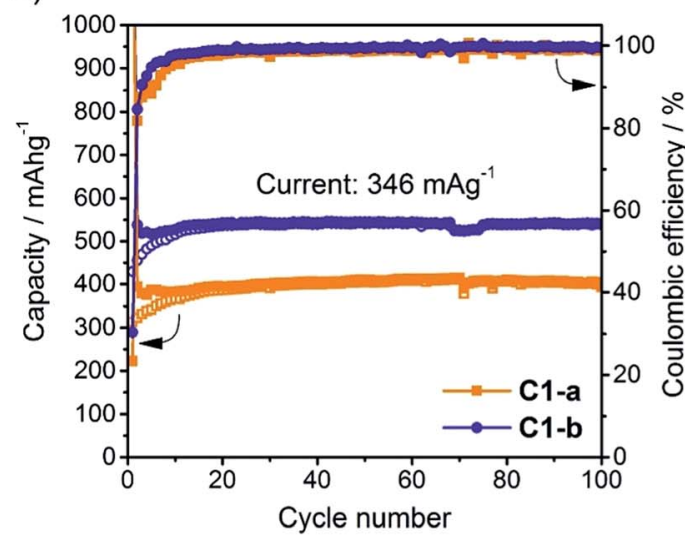

c)

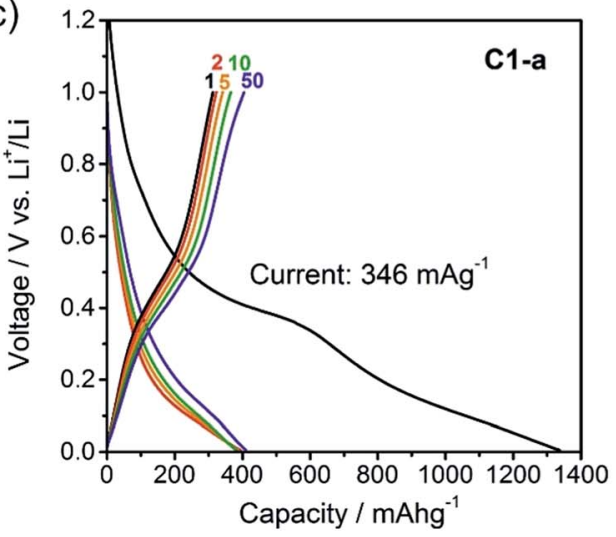

b)
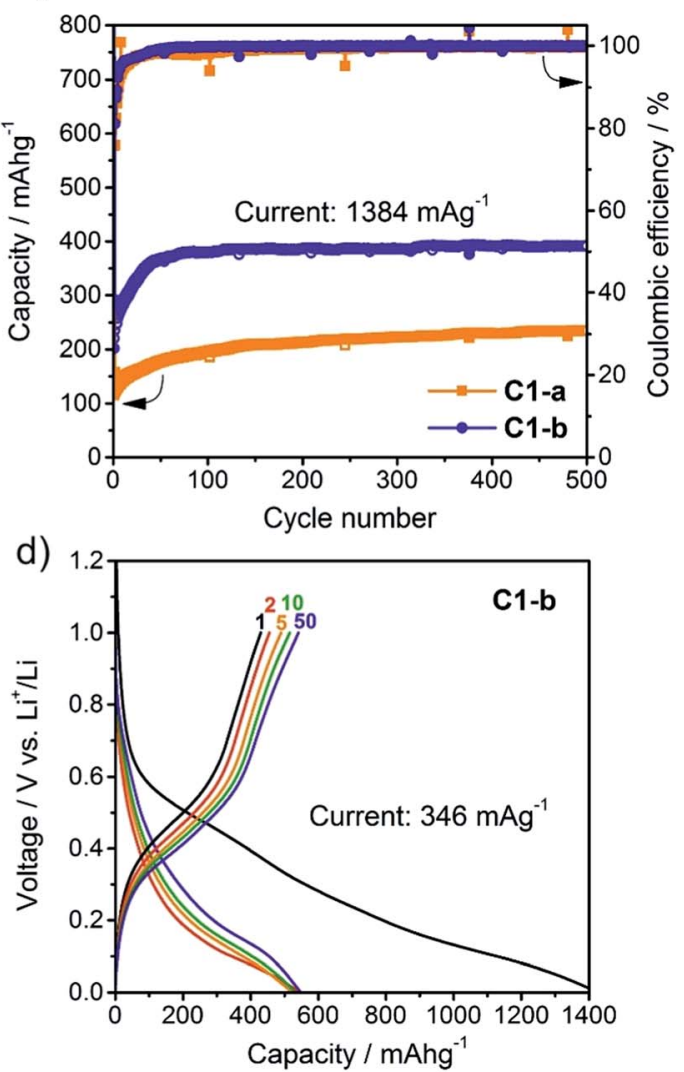

Fig. 7 Electrochemical performance of GeaC materials $\mathrm{C} 1-\mathrm{a}$ and $\mathrm{C} 1-\mathrm{b}$ as anode material for Li-ion batteries. The approximate size of germanium domains is $(51 \pm 6) \mathrm{nm}$ for C1-a and (13 \pm 1$) \mathrm{nm}$ for C1-b. (a) Cycling stability at a current of $346 \mathrm{~mA} \mathrm{~g}^{-1}$. (b) Cycling stability at a current of $1384 \mathrm{~mA} \mathrm{~g}^{-1}$. (c) and (d) Galvanostatic charge and discharge curves of composites C1-a and C1-b at a current of 346 mA g ${ }^{-1}$. All cells were cycled in the potential range $0.005-1.0 \mathrm{~V}$. Capacities and currents are related to the mass of the Ge@C composite corresponding to $80 \%$ of the whole electrodes.

$4 \mathrm{e}^{-} \rightarrow \mathrm{Ge}+2 \mathrm{Li}_{2} \mathrm{O}$. However, during subsequent cycling in all cases the coulombic efficiency, the ratio between charge and discharge capacity, increased to $\sim 99 \%$. For cycling at $346 \mathrm{~mA} \mathrm{~g}^{-1}$ composite C1-b delivers stable capacities of $540 \mathrm{~mA} \mathrm{~h} \mathrm{~g}^{-1}$ with no fading for at least 100 cycles. In contrast, composite C1-a only provides capacities of approximately $400 \mathrm{~mA} \mathrm{~h} \mathrm{~g}^{-1}$. Even at a current of $1384 \mathrm{~mA} \mathrm{~g}^{-1}$ both samples of porous Ge@C material afforded stable capacities for 500 cycles with C1-b showing clearly better rate capability delivering a capacity of $\sim 390 \mathrm{~mA} \mathrm{~h} \mathrm{~g}^{-1}$ compared to $\sim 220 \mathrm{~mA} \mathrm{~h} \mathrm{~g}^{-1}$ for C1a. It is important to note that in all cases currents and capacities were related to the total mass of the Ge@C composite. Considering that EDX-analysis yields a Ge-content of $46.5 \pm$ $2.8 \%$ for $\mathbf{C}-1 \mathrm{a}$ and $39.8 \pm 2.4 \%$ for $\mathbf{C}-\mathbf{1 b}$ the corresponding Ge-content in the electrodes can be estimated at $37 \%$ and $32 \%$ respectively. Relating currents and capacities only to this fraction of Ge in Ge@C, composite C1-b therefore reaches stable capacities of $1360 \mathrm{~mA} \mathrm{~h} \mathrm{~g}^{-1}$ for 100 cycles at a rate of $870 \mathrm{~mA} \mathrm{~g}^{-1}$ and $980 \mathrm{~mA} \mathrm{~h} \mathrm{~g}^{-1}$ for 500 cycles at a rate of $3480 \mathrm{~mA} \mathrm{~g}^{-1}$. Despite the fact that direct comparison of electrochemical results has to be done carefully due to typically differences in electrode composition (e.g. Ge-content) or electrochemical cycling (e.g. current, potential range), we note that the performance of the herein presented Ge@C composite C1-b is indeed comparable with recent reports on $\mathrm{Ge} / \mathrm{C}$ materials (Table $\mathrm{S} 1 \uparrow$ for detailed comparison)..$^{37,48,50,86,87}$ These good electrochemical properties can be attributed to several factors. Due to nanoscale dimension of crystalline germanium in the Ge@C composites, and appropriate porosity, the massive volume changes occurring during lithiation/delithiation can be effectively accommodated, leading to excellent cycling stability. Further, due to the small size of germanium domains, intimate contact with carbon and porous structure of Ge@C, the ionic and electronic conductivity are enhanced allowing fast charging/discharging. In this regard, the significantly superior rate capability obtained for composite C1-b compared to C1-a can be attributed to the smaller size of crystalline primary germanium particles $[(13 \pm 1) \mathrm{nm} v s .(51 \pm$ 6) $\mathrm{nm}$, see Table 2] and therefore shorter diffusion distances. The fact that the capacity does not reach the theoretical maximum at ambient temperature of $1384 \mathrm{~mA} \mathrm{~h} \mathrm{~g}^{-1}$ (assuming formation of $\mathrm{Li}_{15} \mathrm{Ge}_{4}$ ), might be attributed to the relatively high currents used and possibly fractions of germanium oxides as indicated by EDX measurements (Table S2 $\dagger$ ), which leads to lower capacities. For comparison, whereas germanium has a theoretical capacity of $1384 \mathrm{~mA} \mathrm{~h} \mathrm{~g}^{-1}$ the reversible theoretical capacity of $\mathrm{GeO}_{2}$ is $961 \mathrm{~mA} \mathrm{~h} \mathrm{~g}{ }^{-1}$. Fig. 7c and d show the 
galvanostatic charge/discharge curves of composite C1-a and C1-b. In both cases the average delithiation potential is relatively low $(\sim 0.5 \mathrm{~V})$ indicating high suitability of such Ge@C materials for future full cell applications as a high performance alternative to commercial graphite anodes.

\section{Conclusions}

The germanium(II) salicyl alcoholates, germanium(II) 2-(oxidomethyl)phenolate (1), germanium(II) 4-methyl-2-(oxidomethyl) phenolate (2) and germanium(II) 4-bromo-2-(oxidomethyl) phenolate (3), were synthesized by the reaction of Ge $\left[\mathrm{N}\left(\mathrm{SiMe}_{3}\right)_{2}\right]_{2}$ and the respective salicyl alcohols. Dimeric, trimeric and tetrameric structures of the germylenes were determined in the solid state and equilibriums between oligomers of these compounds were observed in solution. Twin polymerization of the compounds 1-3 that was thermally induced by heating up to $230{ }^{\circ} \mathrm{C}$ gave germanium-containing phenolic resin hybrid materials. In contrast to spirocyclic silicon salicyl alcoholates, no influence following the steric and electronic features of their substituents $[\mathrm{R}=\mathrm{H}(\mathbf{1}), \mathrm{Me}(\mathbf{2})$ and $\mathrm{Br}$ (3)] was observed on the process of thermally induced twin polymerization. Moreover, analyses of the as-obtained hybrid materials and bulk syntheses of $\mathrm{Ge} @ \mathrm{C}$ composites and $\mathrm{GeO}_{2}$ support this observation. However, a significant dependency on the solid form of the germylenes e.g., amorphous $v s$. crystalline, was observed for the process of thermally induced twin polymerization. Its initiation is hampered by a densely packed structure in the first place but as the polymerization process is initiated, a pre-organized arrangement of the precursors facilitates the polymerization.

Porous Ge@C composites and non-porous $\mathrm{GeO}_{2}$ were obtained by either conversion of the as-obtained hybrid materials under reductive or oxidative conditions. Testing the obtained Ge@C composites as anode materials for rechargeable lithiumion batteries in order to provide a proof of principle on our concept revealed that excellent cyclability, rate capability and high coulombic efficiency were obtained, especially for the Ge@C composite possessing smaller crystalline germanium primary particle sizes $[(13 \pm 1) \mathrm{nm}]$. Despite the fact that the present cost for germanium compounds is possibly too high for implementing germanium-based anodes in commercial lithium-ion batteries, the herein presented concept of twin polymerization provides a general strategy to prepare highperformance electrode materials by embedding the active material efficiently into a conductive carbon matrix and holds considerable potential to be expanded to further systems in the future.

\section{Experimental section}

All reactions were performed under argon using Schlenk techniques or in a glovebox. Solvents were purified and dried by applying standard techniques. The reactions were carried out with freshly distilled, dried solvents. ${ }^{1} \mathrm{H},{ }^{13} \mathrm{C}\left\{{ }^{1} \mathrm{H}\right\}$ and ${ }^{1} \mathrm{H}^{13} \mathrm{C}\left\{{ }^{1} \mathrm{H}\right\}$ HSQC NMR spectra were recorded with a Bruker Avance III 500 spectrometer. Solid-state NMR spectra were measured at 9.4 T with a Bruker Avance 400 spectrometer equipped with doubletuned probes capable of magic angle spinning (MAS). ${ }^{13} \mathrm{C}\left\{{ }^{1} \mathrm{H}\right\}$ CP-MAS NMR spectra were measured at $100.6 \mathrm{MHz}$ in $3.2 \mathrm{~mm}$ standard zirconium oxide rotors (BRUKER) spinning at $15 \mathrm{kHz}$. Cross polarization (CP) with a contact time of $3 \mathrm{~ms}$ was used to enhance sensitivity. The recycle delay was $5 \mathrm{~s}$. The spectrum was referenced externally to tetramethylsilane (TMS) as well as to adamantane as secondary standard (38.48 ppm for ${ }^{13} \mathrm{C}$ ). All spectra were collected with ${ }^{1} \mathrm{H}$ decoupling using a two-pulse phase modulation sequence. ATR-FT-IR spectra were recorded with a BioRad FTS-165 spectrometer. FT-IR were recorded with a Nicolet IR 200 spectrometer from Thermo Scientific (Thermo Fisher Scientific Inc., Waltham, MA, USA) in a $\mathrm{KBr}$ Matrix. Raman spectra were collected on a LabRam HR800 confocal mirco Raman system equipped with a helium-neon-laser $(\lambda=$ $632.8 \mathrm{~nm}, P=3.08 \mathrm{~mW})$ without usage of any filter $\left(D_{0}\right)$ at fiftyfold magnification. Energy-dispersive X-ray spectroscopy (EDX) and scanning electron microscopy (SEM) were performed using a NovaNano SEM from FEI with the following parameters: pressure ( $\sim 10^{-5} \mathrm{mbar}$ ), work distance (5 to $7 \mathrm{~mm}$ ) and acceleration voltage $(18 \mathrm{kV})$ using a Si Drift Detector XFlash 3001 from Bruker AXS. Transmission electron micrographs were obtained by a $200 \mathrm{kV}$ high resolution transmission electron microscope [HRTEM, CM 20 FEG, Co. Philips (FEI Europe, Europe NanoPort, Eindhoven, The Netherlands)] with imaging energy filter from Gatan (GIF). Melting points were determined with a melting point B-540 apparatus from Büchi. CHN analyses were determined using a FlashEA 1112 NC Analyzer from Thermo Fisher Scientific. DSC experiments were determined with a Mettler Toledo DSC 30 using $40 \mu \mathrm{L}$ aluminum crucibles. The measurements were performed up to $400{ }^{\circ} \mathrm{C}$ with a heating rate of $10 \mathrm{~K} \mathrm{~min}^{-1}$ in $\mathrm{N}_{2}$ atmosphere and a volume flow of $50 \mathrm{~mL} \mathrm{~min}^{-1}$. TGA/DSC experiments were determined with a Mettler Toledo TGA/DSC1 1600 system with a MX1 balance. The measurement was performed from 40 to $800{ }^{\circ} \mathrm{C}$ with a heating rate of $10 \mathrm{~K} \mathrm{~min}^{-1}$ in Ar atmosphere and a volume flow of $60 \mathrm{~mL} \mathrm{~min}^{-1}$. Nitrogen physisorption isotherms were obtained at $-196{ }^{\circ} \mathrm{C}$ using an Autosorb IQ2 apparatus from Quantachrome. All samples were activated in vacuum at $150{ }^{\circ} \mathrm{C}$ for $3 \mathrm{~h}$ prior to the measurements. Specific surface areas were calculated applying the BET equation $\left(p / p_{0}=0.150 \pm 0.002\right)$. The micropore content was estimated according to a QSDFT model (QSDFT: Quenched Solid Density Functional Theory, model for slit and cylindrical pores using the adsorption branch) for carbon samples using the Autosorb 1.56 software from Quantachrome. ${ }^{88-95}$ The specific micropore and total pore volume were also calculated by the above mentioned DFT models. For X-ray photoelectron spectroscopy (XPS) measurements, the powder samples were pressed on indium foil (99.99\%, from MaTeck $\mathrm{GmbH}$ ) that was cleaned with standard solvents in an ultrasonic bath. Measurements were performed in ultra-high vacuum (UHV) employing a hemispherical electron analyzer (PHOIBOS 150 from SPECS GmbH) and an $\mathrm{Al}-\mathrm{K}_{\alpha}$ X-ray source (XR50M from SPECS GmbH) equipped with a monochromator (FOCUS from SPECS GmbH). The pass energy was set to $10 \mathrm{eV}$ for acquisition of the core-level and Auger electron spectra. The estimated error in binding energies 
is $\pm 0.2 \mathrm{eV}$. No charge compensation was applied. Powder X-ray diffraction (PXRD) patterns were collected using a STOE-STADI $\mathrm{P}$ diffractometer from STOE with $\mathrm{Cu}-\mathrm{K}_{\alpha}$ radiation $(40 \mathrm{kV}, 40 \mathrm{~mA})$ and a Ge(111) monochromator. The crystallite size was estimated using the Scherrer equation: $\tau=K \lambda / \beta \cos \theta$, where $\tau$ is the volume weighted crystallite size, $K$ is the Scherrer constant here taken as $1.0, \lambda$ is the $\mathrm{X}$-ray wavelength, $\theta$ is the Bragg angle in ${ }^{\circ}$ and $\beta$ is the full width of the diffraction line at half of the maximum intensity (FWHM, background subtracted). The FWHM is corrected for instrumental broadening using a $\mathrm{LaB}_{6}$ standard (SRM 660) purchased from NIST (National Institute of Standards and Technology). The value of $\beta$ was corrected from $\left(\beta_{\text {measured }}{ }^{2}\right.$ and $\beta_{\text {instrument }}{ }^{2}$ are the FWHMs of measured and standard profiles):

$$
\beta^{2}=\beta_{\text {measured }}{ }^{2}-\beta_{\text {instrument }^{2}} \text {. }
$$

Germanium(Iv) chloride and 1,1,1,3,3,3-hexamethyldisilazane were purchased from ABCR GmbH \& Co KG. $2.5 \mathrm{M}$ $n$-butyllithium and 5-bromo-2-hydroxybenzaldehyde were purchased from Merck Schuchardt OHG (Hohenbrunn). 2-Hydroxybenzyl alcohol and 4-methylphenol were purchased from Alfa Aesar GmbH \& Co KG (Karlsruhe). $\mathrm{GeCl}_{2} \cdot 1,4$ dioxane, ${ }^{15} \mathrm{LiN}\left(\mathrm{SiMe}_{3}\right)_{2},{ }^{15} \mathrm{Ge}\left[\mathrm{N}\left(\mathrm{SiMe}_{3}\right)_{2}\right]_{2}$ (ref. 3) and 2-hydroxy-5methylbenzaldehyde ${ }^{96}$ were synthesized according to the literature procedures. 2-Hydroxy-5-methylbenzyl alcohol, 5-bromo2-hydroxybenzyl alcohol ${ }^{97}$ were synthesized according to modified literature procedures. 2-Hydroxybenzyl alcohol was purified by column chromatography (on silica gel using an ethyl acetate/ $n$-hexane mixture (20/80) as eluent) before usage. All details including syntheses and characterizations of the molecular precursors are given in the ESI. $\dagger$

\subsection{Synthesis of germanium(II) 2-(oxidomethyl)phenolate (1)}

A solution of 2-hydroxybenzyl alcohol $(0.346 \mathrm{~g}, 2.78 \mathrm{mmol})$ in a mixture of diethyl ether $(4 \mathrm{~mL})$ and $n$-pentane $(4 \mathrm{~mL})$ was added dropwise to a solution of $\mathrm{Ge}\left[\mathrm{N}\left(\mathrm{SiMe}_{3}\right)_{2}\right]_{2}(1.096 \mathrm{~g}, 2.78$ $\mathrm{mmol})$ in $n$-pentane $(10 \mathrm{~mL})$ at ambient temperature. A colorless precipitate occurred within $5 \mathrm{~min}$ upon stirring. The mixture was filtered off and washed with $n$-pentane $(3 \times 3 \mathrm{~mL})$ to give amorphous compound $1(0.227 \mathrm{~g})$ after evaporating volatile residues under reduced pressure $\left(10^{-2} \mathrm{mbar}\right)$. Slow evaporation of the volatile solvent gave crystalline $(\mathbf{1})_{4}$ from the filtrate over a period of 2 hours. The colorless crystals were filtered off and all volatile residues were removed by evaporation under reduced pressure $\left(10^{-1} \mathrm{mbar}\right)$ to give crystalline 1 $\left[(1)_{4}, 0.174 \mathrm{~g}\right]$. Yield (both fractions): $0.401 \mathrm{~g}, 73 \%$; $\mathrm{mp}-$ (decomposition above $\sim 101{ }^{\circ} \mathrm{C}$ ); ${ }^{1} \mathrm{H}$ NMR $\left(500 \mathrm{MHz}, \mathrm{d}_{8}\right.$-THF, $25{ }^{\circ} \mathrm{C}, \mathrm{TMS}$ ): $\delta=4.59$ [s (broad), $2 \mathrm{H}, \mathrm{CH}_{2}$ ], 6.66 [m (broad), $\mathrm{H}$, $\mathrm{C}_{6} H_{4}$ ], 6.74 [m (broad), $\mathrm{H}, \mathrm{C}_{6} H_{4}$ ], 6.76 [m (broad), $\mathrm{H}, \mathrm{C}_{6} \mathrm{H}_{4}$ ], 7.12 ppm [m (broad), H, $\left.\mathrm{C}_{6} H_{4}\right] ;{ }^{13} \mathrm{C}\left\{{ }^{1} \mathrm{H}\right\}$ NMR (125 MHz, d $\mathrm{d}_{8}$-THF, $25{ }^{\circ} \mathrm{C}$, TMS $): \delta=62.1\left(C_{2}\right), 119.4\left(C_{6} \mathrm{H}_{4}\right), 119.6\left(C_{6} \mathrm{H}_{4}\right), 120.3$ $\left(C_{6} \mathrm{H}_{4}\right), 128.3\left(C_{6} \mathrm{H}_{4}\right), 130.4\left(C_{6} \mathrm{H}_{4}\right), 158.4 \mathrm{ppm}\left(C_{6} \mathrm{H}_{4}\right) ;{ }^{1} \mathrm{H}^{13} \mathrm{C}\left\{{ }^{1} \mathrm{H}\right\}$ HSQC NMR (125 MHz, d ${ }_{8}$-THF, $25^{\circ} \mathrm{C}$, TMS): $\delta=4.60 / 59.1\left(\mathrm{CH}_{2}\right)$, 6.64/116.6 $\left(\mathrm{C}_{6} H_{4}\right), 6.73 / 117.2\left(\mathrm{C}_{6} H_{4}\right), 6.77 / 125.1\left(C_{6} H_{4}\right), 7.10 /$ $127.0 \mathrm{ppm}\left(C_{6} H_{4}\right)$; ATR-FT-IR: $3066\left(\nu \mathrm{C}_{\text {Aryl }}-\mathrm{H}\right), 3037\left(\nu \mathrm{C}_{\text {Aryl }}-\mathrm{H}\right)$, $3015\left(\nu \mathrm{C}_{\mathrm{Aryl}}-\mathrm{H}\right), 2921\left(\nu \mathrm{CH}_{2}\right), 2857\left(\nu \mathrm{CH}_{2}\right), 1599(\nu \mathrm{C}=\mathrm{C}), 1578$ $(\nu \mathrm{C}=\mathrm{C}), 1478\left(\delta \mathrm{CH}_{2}\right), 1453\left(\delta \mathrm{CH}_{2}\right), 1254(\nu \mathrm{C}-\mathrm{O}), 1198(\nu \mathrm{C}-\mathrm{O})$, $756\left(\gamma \mathrm{C}_{6} \mathrm{H}_{4}\right), 731\left(\gamma \mathrm{C}_{6} \mathrm{H}_{4}\right), 633(\nu \mathrm{Ge}-\mathrm{O}), 604(\nu \mathrm{Ge}-\mathrm{O}), 556$ and 525 and 486 and $444 \mathrm{~cm}^{-1}$ (O-Ge-O/Ge-O-Ge); CHN analysis calcd (\%) for $\mathrm{C}_{7} \mathrm{H}_{6} \mathrm{GeO}_{2}$ : C, 43.17; $\mathrm{H}, 3.11$; found: $\mathrm{C}, 43.26 ; \mathrm{H}$, 3.55. Single crystals suitable for X-ray diffraction analysis were obtained (i) directly from the filtrate of the reaction mixture after filtration of the precipitate to give $2 \cdot(\mathbf{1})_{4} \cdot n$-pentane, (ii) by evaporation of the solvent at ambient temperature of a saturated solution of $\mathbf{1}$ in diethyl ether and (iii) by cooling a saturated solution of $(\mathbf{1})_{4}$ in diethyl ether to $-18{ }^{\circ} \mathrm{C}$ to give $(\mathbf{1})_{3}$, respectively.

\subsection{Synthesis of germanium(II) 4-methyl-2-(oxidomethyl) phenolate (2)}

A solution of 2-hydroxy-5-methylbenzyl alcohol (0.454 g, 3.29 $\mathrm{mmol})$ in a mixture of diethyl ether $(6 \mathrm{~mL})$ and $n$-pentane $(2 \mathrm{~mL})$ was added dropwise to a solution of $\mathrm{Ge}\left[\mathrm{N}\left(\mathrm{SiMe}_{3}\right)_{2}\right]_{2}(1.294 \mathrm{~g}$, $3.29 \mathrm{mmol})$ in $n$-pentane $(10 \mathrm{~mL})$ at ambient temperature. A colorless precipitate occurred within $5 \mathrm{~min}$ upon stirring. The mixture was filtered off and washed with $n$-pentane $(3 \times 2 \mathrm{~mL})$ to give amorphous compound 2 (0.168 g) after evaporating volatile residues under reduced pressure $\left(10^{-2} \mathrm{mbar}\right)$. Slow evaporation of the volatile solvent gave crystalline 2 from the filtrate over a period of 2 hours. Filtration and evaporation of all volatile residues under reduced pressure $\left(10^{-1} \mathrm{mbar}\right)$ gave 2 $(0.288 \mathrm{~g})$ as colorless crystals. Yield (both fractions): $0.456 \mathrm{~g}$, $66 \%$; mp - (decomposition above $\left.\sim 164{ }^{\circ} \mathrm{C}\right) ;{ }^{1} \mathrm{H}$ NMR $(500 \mathrm{MHz}$, $\mathrm{d}_{8}$-THF, $25^{\circ} \mathrm{C}, \mathrm{TMS}$ ): $\delta=2.20$ [s (broad), 3H, Me], 4.61 [s (broad), $2 \mathrm{H}, \mathrm{CH}_{2}$ ], 6.57 [m (broad), $\mathrm{H}, \mathrm{C}_{6} H_{3}$ ], 6.82 [m (broad), $\mathrm{H}, \mathrm{C}_{6} H_{3}$ ], $6.97 \mathrm{ppm}$ [m (broad), H, $\left.\mathrm{C}_{6} \mathrm{H}_{3}\right] ;{ }^{13} \mathrm{C}\left\{{ }^{1} \mathrm{H}\right\} \mathrm{NMR}\left(125 \mathrm{MHz}, \mathrm{d}_{8}\right.$-THF, $\left.25{ }^{\circ} \mathrm{C}, \mathrm{TMS}\right): \delta=20.8(\mathrm{Me}), 62.5\left(\mathrm{CH}_{2}\right), 115.9\left(C_{6} \mathrm{H}_{3}\right), 128.4$ $\left(C_{6} \mathrm{H}_{3}\right), 128.6\left(C_{6} \mathrm{H}_{3}\right), 128.7\left(C_{6} \mathrm{H}_{3}\right), 129.0\left(C_{6} \mathrm{H}_{3}\right), 154.5 \mathrm{ppm}$ $\left(C_{6} \mathrm{H}_{3}\right) ;{ }^{1} \mathrm{H}^{13} \mathrm{C}\left\{{ }^{1} \mathrm{H}\right\}$ HSQC NMR (125 MHz, $\left.\mathrm{d}_{8}-\mathrm{THF}, 25{ }^{\circ} \mathrm{C}, \mathrm{TMS}\right)$ : $\delta=2.20 / 23.1(\mathrm{Me}), 4.61 / 64.9\left(\mathrm{CH}_{2}\right), 6.57 / 118.3\left(\mathrm{C}_{6} \mathrm{H}_{3}\right), 6.82 / 131.3$ $\left(C_{6} H_{3}\right), 6.97 / 131.2 \mathrm{ppm}\left(\mathrm{C}_{6} H_{3}\right)$; ATR-FT-IR: $3014\left(\nu \mathrm{C}_{\mathrm{Aryl}}-\mathrm{H}\right), 2909$ $\left(\nu \mathrm{CH}_{3} / \mathrm{CH}_{2}\right), 2861\left(\nu \mathrm{CH}_{3} / \mathrm{CH}_{2}\right), 1613(\nu \mathrm{C}=\mathrm{C}), 1578(\nu \mathrm{C}=\mathrm{C})$, $1484\left(\delta \mathrm{CH}_{3} / \mathrm{CH}_{2}\right), 1451\left(\delta \mathrm{CH}_{3} / \mathrm{CH}_{2}\right), 1252(\nu \mathrm{C}-\mathrm{O}), 1214(\nu \mathrm{C}-\mathrm{O})$, $872\left(\gamma \mathrm{C}_{6} \mathrm{H}_{3}\right), 818\left(\gamma \mathrm{C}_{6} \mathrm{H}_{3}\right), 644(\nu \mathrm{Ge}-\mathrm{O}), 556$ and 490 and 459 $\mathrm{cm}^{-1}(\mathrm{O}-\mathrm{Ge}-\mathrm{O} / \mathrm{Ge}-\mathrm{O}-\mathrm{Ge})$; $\mathrm{CHN}$ analysis calcd (\%) for $\mathrm{C}_{8} \mathrm{H}_{8} \mathrm{GeO}_{2}$ : C, 46.02; H, 3.86; found: C, 45.79; H, 4.00. Single crystals suitable for X-ray diffraction analysis were obtained by slow evaporation of the solvent at ambient temperature of a saturated solution of 2 in diethyl ether to give $(2)_{2}$.

\subsection{Synthesis of germanium(II) 4-bromo-2-(oxidomethyl) phenolate (3)}

A solution of 5-bromo-2-hydroxybenzyl alcohol (0.525 g, 2.58 $\mathrm{mmol})$ in a mixture of diethyl ether $(10 \mathrm{~mL})$ and $n$-hexane $(5 \mathrm{~mL})$ was added dropwise to a solution of $\mathrm{Ge}\left[\mathrm{N}\left(\mathrm{SiMe}_{3}\right)_{2}\right]_{2}(1.018 \mathrm{~g}$, $2.59 \mathrm{mmol})$ in a mixture of diethyl ether $(2 \mathrm{~mL})$ and $n$-hexane $(10 \mathrm{~mL})$ at ambient temperature. A colorless precipitate occurred within 5 min upon stirring. The mixture was filtered off and washed with $n$-hexane $(3 \times 3 \mathrm{~mL})$ to give amorphous compound 3 (0.387 g) after evaporating volatile residues under reduced pressure $\left(10^{-2}\right.$ mbar). Yield: $0.457 \mathrm{~g}, 64 \%$; mp - (decomposition 
above $\left.\sim 151{ }^{\circ} \mathrm{C}\right) ;{ }^{1} \mathrm{H}$ NMR (500 MHz, $\mathrm{d}_{8}$-THF, $25{ }^{\circ} \mathrm{C}$, TMS): $\delta=$ 4.59 (s, 2H, $\mathrm{CH}_{2}$ ), 6.65 (d, H, $\left.\mathrm{C}_{6} H_{3},{ }^{3} J_{\text {ortho }}=8.5 \mathrm{~Hz}\right), 6.97$ (d, H, $\left.\mathrm{C}_{6} H_{3},{ }^{4} J_{\text {meta }}=1.9 \mathrm{~Hz}\right), 7.23 \mathrm{ppm}\left(\mathrm{dd}, \mathrm{H}, \mathrm{C}_{6} H_{3},{ }^{3} J_{\text {ortho }}=8.5 \mathrm{~Hz}\right.$, $\left.{ }^{4} J_{\text {meta }}=1.9 \mathrm{~Hz}\right) ;{ }^{13} \mathrm{C}\left\{{ }^{1} \mathrm{H}\right\}$ NMR (125 MHz, d ${ }_{8}$ THF, $25{ }^{\circ} \mathrm{C}$, TMS): $\delta=62.0\left(C_{2}\right), 111.2\left(C_{6} \mathrm{H}_{3}\right), 122.1\left(C_{6} \mathrm{H}_{3}\right), 130.8\left(C_{6} \mathrm{H}_{3}\right), 131.4$ $\left(C_{6} \mathrm{H}_{3}\right), 132.8\left(C_{6} \mathrm{H}_{3}\right), 157.5 \mathrm{ppm}\left(C_{6} \mathrm{H}_{3}\right) ;{ }^{1} \mathrm{H}^{13} \mathrm{C}\left\{{ }^{1} \mathrm{H}\right\}$ HSQC NMR (125 MHz, d ${ }_{8}$-THF, $25{ }^{\circ} \mathrm{C}$, TMS): $\delta=4.59 / 58.9\left(\mathrm{CH}_{2}\right), 6.65 / 119.0$ $\left(C_{6} H_{3}\right), 6.98 / 127.7\left(C_{6} H_{3}\right), 7.24 / 129.9 \mathrm{ppm}\left(C_{6} H_{3}\right)$; ATR-FT-IR: $3066\left(\nu \mathrm{C}_{\mathrm{Aryl}}-\mathrm{H}\right), 2973\left(\nu \mathrm{C}_{\mathrm{Aryl}}-\mathrm{H}\right), 2913\left(\nu \mathrm{CH}_{2}\right), 2867\left(\nu \mathrm{CH}_{2}\right)$, $1590(\nu \mathrm{C}=\mathrm{C}), 1561(\nu \mathrm{C}=\mathrm{C}), 1472\left(\delta \mathrm{CH}_{2}\right), 1406\left(\delta \mathrm{CH}_{2}\right), 1254(\nu$ $\mathrm{C}-\mathrm{O}), 1225(\nu \mathrm{C}-\mathrm{O}), 1073(\nu \mathrm{C}-\mathrm{Br}), 874\left(\gamma \mathrm{C}_{6} \mathrm{H}_{4}\right), 822\left(\gamma \mathrm{C}_{6} \mathrm{H}_{4}\right), 656$ $(\nu \mathrm{Ge}-\mathrm{O}), 544$ and $440 \mathrm{~cm}^{-1}(\mathrm{O}-\mathrm{Ge}-\mathrm{O} / \mathrm{Ge}-\mathrm{O}-\mathrm{Ge})$; CHN analysis calcd (\%) for $\mathrm{C}_{7} \mathrm{H}_{5} \mathrm{BrGeO}_{2}$ : C, 30.72; $\mathrm{H}, 1.84$; found: $\mathrm{C}, 30.40 ; \mathrm{H}$, 1.69. Single crystals suitable for $\mathrm{X}$-ray diffraction analysis were obtained by slow evaporation of the solvent at ambient temperature of a saturated solution of 3 in 1,4-dioxane to give $(3)_{2} \cdot 1,4$-dioxane.

4.4 General procedure for the synthesis of phenolic resin/ germanium oxide hybrid materials by thermally induced twin polymerization in melt - exemplified for compound 1

Compound 1 (0.507 g, $2.60 \mathrm{mmol})$ was polymerized at $200{ }^{\circ} \mathrm{C}$ under Ar atmosphere and treated at this temperature for 3 hours. The obtained solid was washed with dichloromethane $(10 \times 3 \mathrm{~mL})$ and dried under reduced pressure $\left(10^{-1} \mathrm{mbar}\right)$ in order to remove volatile by-products. The product HM-1 $[0.471 \mathrm{~g}, 92 \%, \mathrm{CHN}$ analysis (\%) found: C, 42.38; H, 3.38; EDX analysis (\%) found: C, $54.1 \pm 2.4 ; \mathrm{O}, 18.7 \pm 0.9 ; \mathrm{Ge}, 27.2 \pm 0.6]$ was a pale yellow phenolic resin/germanium oxide monolith; polymerization of: $2(0.507 \mathrm{~g}$, $2.04 \mathrm{mmol}$ ) at $220^{\circ} \mathrm{C}$ gave $\mathbf{H M}-2$ [0.417 g, 97\%, CHN analysis (\%) found: $\mathrm{C}, 47.11$; H, 4.44; EDX analysis (\%) found: C, $55.9 \pm 2.3$; O, $17.6 \pm 0.8 ; \mathrm{Ge}, 26.5 \pm 0.5$ ] as a yellow monolith; $3(0.876 \mathrm{~g}, 3.20$ $\mathrm{mmol}$ ) at $230{ }^{\circ} \mathrm{C}$ gave $\mathbf{H M}-3$ [0.861 g, 98\%, CHN analysis (\%) found: $\mathrm{C}, 30.10$; $\mathrm{H}, 1.77$; EDX analysis (\%) found: $\mathrm{C}, 33.4 \pm 3.1$; O, $10.8 \pm 1.1 ;$ Ge, $27.8 \pm 0.9 ; \mathrm{Br}, 28.0 \pm 0.9]$ as colorless clumps.

4.5 General procedure for the synthesis of porous $\mathrm{Ge} @ \mathrm{C}$ materials - exemplified for hybrid material HM-1

HM-1 (0.136 g) was carbonized under reductive conditions in a stove (deposited in a quartz glass tube) for $3 \mathrm{~h}$ with a final temperature of $800{ }^{\circ} \mathrm{C}$ (heating ramp of $10 \mathrm{~K} \mathrm{~min}^{-1}$ ) under $\mathrm{Ar} / \mathrm{H}_{2}$ flux $\left(95 / 5,20 \mathrm{~L} \mathrm{~h}^{-1}\right)$ to give $\mathbf{C - 1 a}[0.065 \mathrm{~g}$, single point BETsurface area determined at $p / p_{0}=0.150 \pm 0.002: 268 \mathrm{~m}^{2} \mathrm{~g}^{-1}$; CHN analysis (\%) found: C, 32.66; H, 0.29; EDX analysis (\%) found: $\mathrm{C}, 44.3 \pm 4.1 ; \mathrm{O}, 9.2 \pm 1.4 ; \mathrm{Ge}, 46.5 \pm 2.8$; crystalline Ge particle size determined by applying the Scherer equation based on the (220) reflection of Ge ICDD no. C03-065-0333: (51 \pm 6$)$ $\mathrm{nm}$ ] as metallic shiny black solid; carbonization of: HM-1 (0.229 $\mathrm{g}$ ) at $600{ }^{\circ} \mathrm{C}$ gave $\mathbf{C - 1 b}[0.110 \mathrm{~g}$, single point BET-surface area: $238 \mathrm{~m}^{2} \mathrm{~g}^{-1}$; CHN analysis (\%) found: C, 34.41; H, 0.86; EDX analysis (\%) found: C, $58.5 \pm 7.5 ; \mathrm{O}, 1.7 \pm 0.3$; Ge, $39.8 \pm 2.4$; crystalline Ge particle size: $(13 \pm 1) \mathrm{nm}]$; HM-2 $(0.123 \mathrm{~g})$ at $800{ }^{\circ} \mathrm{C}$ gave $\mathbf{C}-2[0.057 \mathrm{~g}$, single point BET-surface area: $244 \mathrm{~m}^{2} \mathrm{~g}^{-1}$; CHN analysis (\%) found: C, 31.58; H, 0.18; EDX analysis (\%) found: C, 55.2 \pm 6.7; O, $8.2 \pm 1.2$; Ge, $36.6 \pm 2.0$; crystalline Ge particle size: (39 \pm 3$) \mathrm{nm}$ ]; HM-3 (0.371 g) at
$800{ }^{\circ} \mathrm{C}$ gave $\mathbf{C}-3$ [0.119 g, single point BET-surface area: $418 \mathrm{~m}^{2}$ $\mathrm{g}^{-1}$; CHN analysis (\%) found: C, 60.89; H, 0.38; EDX analysis (\%) found: $\mathrm{C}, 70.4 \pm 8.7 ; \mathrm{O}, 3.1 \pm 0.5 ; \mathrm{Ge}, 26.5 \pm 1.6 ; \mathrm{Br}$, -; crystalline Ge particle size: $(38 \pm 3) \mathrm{nm}]$.

\subsection{General procedure for the synthesis of germanium oxide - exemplified for hybrid material HM-1}

HM-1 (0.218 g) was oxidized in a stove (deposited in a quartz glass tube) for $3 \mathrm{~h}$ with a final temperature of $800{ }^{\circ} \mathrm{C}$ (heating ramp of $\left.10 \mathrm{~K} \mathrm{~min}^{-1}\right)$ under air flux $\left(200 \mathrm{~L} \mathrm{~h}^{-1}\right)$ to give $\mathbf{O x - 1}$ [0.115 $\mathrm{g}$, single point BET-surface area determined at $p / p_{0}=0.150 \pm$ 0.002: $12 \mathrm{~m}^{2} \mathrm{~g}^{-1}$; CHN analysis (\%) found: C, 0.51; EDX analysis (\%) found: C, $3.5 \pm 0.7$; O, $31.0 \pm 3.7$; Ge, $65.5 \pm 3.7$; Raman spectroscopy and PXRD confirmed the presence of hexagonal ( $\alpha$-quartz-like structure ICDD no. C00-036-1463) and tetragonal (rutile-like structure ICDD no. C00-035-0729) $\mathrm{GeO}_{2}$ ] as gray brittle monolith; oxidation of: HM-2 $(0.241 \mathrm{~g})$ gave Ox-2 [0.117 g, single point BET-surface area: $9 \mathrm{~m}^{2} \mathrm{~g}^{-1}$; CHN analysis (\%) found: C, 0.22; EDX analysis (\%) found: C, $3.1 \pm 0.8$; O, $28.7 \pm$ 3.9; Ge, $68.2 \pm 4.1$; Raman spectroscopy and PXRD confirmed the presence of hexagonal and tetragonal $\mathrm{GeO}_{2}$ ]; HM-3 (0.306 g) gave Ox-3 [0.082 g, single point BET-surface area: $20 \mathrm{~m}^{2} \mathrm{~g}^{-1}$; CHN analysis (\%) found: C, 0.60; EDX analysis (\%) found: C, 3.3 \pm 0.6 ; O, $31.2 \pm 3.4$; Ge, $65.5 \pm 3.3$; Br, -; Raman spectroscopy and PXRD confirmed only the presence of hexagonal $\mathrm{GeO}_{2}$ ].

\subsection{Single crystal X-ray diffraction analyses}

Crystallographic data of the compounds $(\mathbf{1})_{3}, 2 \cdot(\mathbf{1})_{4} \cdot n$-pentane, $(2)_{2}$ and $(3)_{2} \cdot 1,4$-dioxane were collected with an Oxford Gemini $S$ diffractometer (CrysAlis RED Version 1.171.32.5 from Oxford Diffraction Ltd.) using Mo-K $\mathrm{K}_{\alpha}(\lambda=0.71073 \AA)$ at $100 \mathrm{~K}\left[(\mathbf{1})_{3}\right]$ or $\mathrm{Cu}-\mathrm{K}_{\alpha}$ radiation $(\lambda=1.54184 \AA)$ at $110 \mathrm{~K}\left[2 \cdot(\mathbf{1})_{4} \cdot n\right.$-pentane and $\left.(2)_{2}\right]$ or $100 \mathrm{~K}\left[(3)_{2}\right]$. The structures were solved by direct methods using SHELXS-2013 and refined by full matrix leastsquare procedures on $F^{2}$ using SHELXL-2013. ${ }^{98}$ Absorption corrections were semi-empirical from equivalents. All nonhydrogen atoms were refined anisotropically and a riding model was employed in the refinement of hydrogen atom positions. The crystallographic data for $(1)_{3}, 2 \cdot(1)_{4} \cdot n$-pentane, $(2)_{2}$ and $(3)_{2} \cdot 1$,4-dioxane have been deposited at the Cambridge Crystallographic Data Centre as supplementary publications CCDC $1438301\left[(1)_{3}\right]$, CCDC $1438303\left[2 \cdot(1)_{4} \cdot n\right.$-pentane $]$, CCDC $1438302\left[(2)_{2}\right]$ and CCDC $1438300\left[(3)_{2} \cdot 1,4\right.$-dioxane $]$.

\subsection{Computational details}

The quantum chemical calculations were carried out at the DFT-D (B3LYP-D3/def2-TZVPP) level of theory using the TURBOMOLE program package. ${ }^{\text {99-106 }}$ All structure data given as xyzfiles in the ESI $\dagger$ were obtained by relaxing all degrees of freedom and confirmed as minima by normal mode analysis.

\subsection{Electrode fabrication, cell assembly and electrochemical measurements}

Ge@C samples, carbon black (CB, Super C65, TIMCAL), and carboxymethyl cellulose (CMC, Grade: 2200, Daicel Fine Chem 
Ltd.) were mixed in the ratio $8: 1: 1$ with deionized water using a Fritsch Pulverisette 7 classic planetary mill (1 hour at 500 $\mathrm{rpm})$. The resulting aqueous slurries were coated onto $\mathrm{Cu}$ foil ( $9 \mu \mathrm{m}, \mathrm{MTI}$ Corporation) and subsequently dried at $80{ }^{\circ} \mathrm{C}$ for 12 hours under vacuum. Electrochemical measurements were conducted in air tight coin-type cells assembled in an Ar-filled glove box $\left(\mathrm{O}_{2}<0.1 \mathrm{ppm}, \mathrm{H}_{2} \mathrm{O}<0.1 \mathrm{ppm}\right)$ using elemental lithium as both counter and reference electrode. $1 \mathrm{M} \mathrm{LiPF}_{6}$ in a $1: 1$ mixture by wt of ethylene carbonate (EC) and dimethyl carbonate (DMC) (Merck, battery grade) with 3\% fluoroethylene carbonate (FEC, Hisunny Chemical Co., battery grade) served as electrolyte. As separator glass fiber (GF/D, Whatman) was used. Galvanostatic cycling tests were carried out at ambient temperature on MPG2 multi-channel workstation (BioLogic).

\section{Acknowledgements}

We gratefully acknowledge financial support by the DFG Forschergruppe 1497 "Organic-Inorganic Nanocomposites through Twin polymerization" and the Fonds der Chemischen Industrie for a fellowship (P. K.). M. Walter and M. V. Kovalenko thank the CTI Swiss Competence Centers for Energy Research (SCCER, 'Heat and Electricity Storage') for financial support. We thank N. Rüffer for TGA measurements, M. Weber for recording the Raman spectra and Prof. Dr M. Hietschold and Dr S. Schulze for recording the TEM images.

\section{References}

1 M. D. Curtis and R. C. Job, Abstr. Pap., Jt. Conf.-Chem. Inst. Can. Am. Chem. Soc., 1972, 12.

2 K. Triplett and M. D. Curtis, J. Am. Chem. Soc., 1975, 97, 5747-5751.

3 D. H. Harris and M. F. Lappert, J. Chem. Soc., Chem. Commun., 1974, 895-896.

4 P. Riviere, J. Satgé and A. Castel, C. R. Seances Acad. Sci., Ser. C, 1975, 281, 835-838.

5 W. P. Neumann, Chem. Rev., 1991, 91, 311-334.

6 A. Castel, P. Riviere, J. Satgé and M. Ahbala, J. Organomet. Chem., 1987, 331, 11-21.

7 A. Castel, P. Riviere, J. Satgé, J. J. E. Moreau and R. J. P. Corriu, Organometallics, 1983, 2, 1498-1502.

8 P. Jutzi, B. Hampel, M. B. Hursthouse and A. J. Howes, J. Organomet. Chem., 1986, 299, 19-27.

9 S. L. Ellis, P. B. Hitchcock, S. A. Holmes, M. F. Lappert and M. J. Slade, J. Organomet. Chem., 1993, 444, 95-99.

10 J. Baumgartner and C. Marschner, Rev. Inorg. Chem., 2014, 34, 119-152.

11 J. Satgé, M. Massol and P. Riviere, J. Organomet. Chem., 1973, 56, 1-39.

12 L. Lange, B. Meyer and W. W. Dumont, J. Organomet. Chem., 1987, 329, C17-C20.

13 J. Pfeiffer, M. Noltemeyer and A. Meller, Z. Anorg. Allg. Chem., 1989, 572, 145-150.

14 B. Cetinkaya, I. Gumrukcu, M. F. Lappert, J. L. Atwood, R. D. Rogers and M. J. Zaworotko, J. Am. Chem. Soc., 1980, 102, 2088-2089.
15 T. Fjeldberg, A. Haaland, B. E. R. Schilling, M. F. Lappert and A. J. Thorne, J. Chem. Soc., Dalton Trans., 1986, 15511556.

16 S. R. Stobart, M. R. Churchill, F. J. Hollander and W. J. Youngs, J. Chem. Soc., Chem. Commun., 1979, 911-912.

17 N. Zhao, J. Zhang, Y. Yang, G. Chen, H. Zhu and H. W. Roesky, Organometallics, 2013, 32, 762-769.

18 Z. D. Brown, J. D. Erickson, J. C. Fettinger and P. P. Power, Organometallics, 2013, 32, 617-622.

19 Z. D. Brown and P. P. Power, Inorg. Chem., 2013, 52, 62486259.

20 Z. D. Brown, P. Vasko, J. D. Erickson, J. C. Fettinger, H. M. Tuononen and P. P. Power, J. Am. Chem. Soc., 2013, 135, 6257-6261.

21 J. W. Dube, Z. D. Brown, C. A. Caputo, P. P. Power and P. J. Ragogna, Chem. Commun., 2014, 50, 1944-1946.

22 Y. Peng, J.-D. Guo, B. D. Ellis, Z. Zhu, J. C. Fettinger, S. Nagase and P. P. Power, J. Am. Chem. Soc., 2009, 131, 16272-16282.

23 J. K. West and L. Stahl, Organometallics, 2012, 31, 20422052.

24 A. Jana, V. Huch and D. Scheschkewitz, Angew. Chem., Int. Ed., 2013, 52, 12179-12182.

25 P. S. Billone, K. Beleznay, C. R. Harrington, L. A. Huck and W. J. Leigh, J. Am. Chem. Soc., 2011, 133, 10523-10534.

26 S. Yao, C. van Wüllen and M. Driess, Chem. Commun., 2008, 5393-5395.

27 U. Anandhi and P. R. Sharp, Inorg. Chim. Acta, 2006, 359, 3521-3526.

28 K. Revunova and G. I. Nikonov, Dalton Trans., 2015, 44, 840866.

29 S. B. Kim, P. Sinsermsuksakul, A. S. Hock, R. D. Pike and R. G. Gordon, Chem. Mater., 2014, 26, 3065-3073.

30 F.-W. Yuan and H.-Y. Tuan, Chem. Mater., 2014, 26, 21722179.

31 T. Kennedy, E. Mullane, H. Geaney, M. Osiak, C. O'Dwyer and K. M. Ryan, Nano Lett., 2014, 14, 716-723.

32 E. Mullane, T. Kennedy, H. Geaney and K. M. Ryan, ACS Appl. Mater. Interfaces, 2014, 6, 18800-18807.

33 Y. Liu, S. Zhang and T. Zhu, ChemElectroChem, 2014, 1, 706713.

34 G. H. Yue, X. Q. Zhang, Y. C. Zhao, Q. S. Xie, X. X. Zhang and D. L. Peng, RSC Adv., 2014, 4, 21450-21455.

35 M. Veith, M. Ehses and V. Huch, New J. Chem., 2005, 29, 154-164.

36 S. Jin, N. Li, H. Cui and C. Wang, ACS Appl. Mater. Interfaces, 2014, 6, 19397-19404.

37 J. Liu, K. Song, C. Zhu, C.-C. Chen, P. A. van Aken, J. Maier and Y. Yu, ACS Nano, 2014, 8, 7051-7059.

38 L. Y. Lim, N. Liu, Y. Cui and M. F. Toney, Chem. Mater., 2014, 26, 3739-3746.

39 N. Nitta and G. Yushin, Part. Part. Syst. Charact., 2014, 31, 317-336.

40 H. Jia, R. Klöpsch, X. He, J. P. Badillo, M. Winter and T. Placke, J. Mater. Chem. A, 2014, 2, 17545-17550.

41 M. Liu, X. Ma, L. Gan, Z. Xu, D. Zhu and L. Chen, J. Mater. Chem. A, 2014, 2, 17107-17114. 
42 M.-H. Seo, M. Park, K. T. Lee, K. Kim, J. Kim and J. Cho, Energy Environ. Sci., 2011, 4, 425-428.

43 K. C. Klavetter, S. M. Wood, Y.-M. Lin, J. L. Snider, N. C. Davy, A. M. Chockla, D. K. Romanovicz, B. A. Korgel, J.-W. Lee, A. Heller and C. B. Mullins, J. Power Sources, 2013, 238, 123-136.

44 L. P. Tan, Z. Lu, H. T. Tan, J. Zhu, X. Rui, Q. Yan and H. H. Hng, J. Power Sources, 2012, 206, 253-258.

45 A. Jahel, A. Darwiche, C. Matei Ghimbeu, C. Vix-Guterl and L. Monconduit, J. Power Sources, 2014, 269, 755-759.

46 G. Cui, L. Gu, L. Zhi, N. Kaskhedikar, P. A. van Aken, K. Müllen and J. Maier, Adv. Mater., 2008, 20, 3079-3083.

47 M.-H. Park, Y. Cho, K. Kim, J. Kim, M. Liu and J. Cho, Angew. Chem., Int. Ed., 2011, 50, 9647-9650.

48 Y. Xiao, M. Cao, L. Ren and C. Hu, Nanoscale, 2012, 4, 74697474.

49 S. Yoon, C.-M. Park and H.-J. Sohn, Electrochem. Solid-State Lett., 2008, 11, A42-A45.

50 D.-J. Xue, S. Xin, Y. Yan, K.-C. Jiang, Y.-X. Yin, Y.-G. Guo and L.-J. Wan, J. Am. Chem. Soc., 2012, 134, 2512-2515.

51 X. Li, J. Liang, Z. Hou, Y. Zhu, Y. Wang and Y. Qian, Chem. Commun., 2015, 51, 3882-3885.

52 W. Li, M. Li, Z. Yang, J. Xu, X. Zhong, J. Wang, L. Zeng, X. Liu, Y. Jiang, X. Wei, L. Gu and Y. Yu, Small, 2015, 11, 2762-2767.

53 T. Kennedy, M. Bezuidenhout, K. Palaniappan, K. Stokes, M. Brandon and K. M. Ryan, ACS Nano, 2015, 9, 74567465.

54 T. Wang, G. Xie, J. Zhu and B. Lu, Electrochim. Acta, 2015, 186, 64-70.

55 S. Spange, P. Kempe, A. Seifert, A. A. Auer, P. Ecorchard, H. Lang, M. Falke, M. Hietschold, A. Pohlers, W. Hoyer, G. Cox, E. Kockrick and S. Kaskel, Angew. Chem., Int. Ed., 2009, 48, 8254-8258.

56 S. Grund, P. Kempe, G. Baumann, A. Seifert and S. Spange, Angew. Chem., Int. Ed., 2007, 46, 628-632.

57 A. A. Auer, A. Richter, A. V. Berezkin, D. V. Guseva and S. Spange, Macromol. Theory Simul., 2012, 21, 615-628.

58 P. Kempe, T. Löschner, A. A. Auer, A. Seifert, G. Cox and S. Spange, Chem.-Eur. J., 2014, 20, 8040-8053.

59 P. Kempe, T. Löschner, D. Adner and S. Spange, New J. Chem., 2011, 35, 2735-2739.

60 T. Löschner, A. Mehner, S. Grund, A. Seifert, A. Pohlers, A. Lange, G. Cox, H. J. Hähnle and S. Spange, Angew. Chem., Int. Ed., 2012, 51, 3258-3261.

61 A. Mehner, A. Pohlers, W. Hoyer, G. Cox and S. Spange, Macromol. Chem. Phys., 2013, 214, 1000-1010.

62 S. Spange and S. Grund, Adv. Mater., 2009, 21, 2111-2116.

63 T. Ebert, A. Seifert and S. Spange, Macromol. Rapid Commun., 2015, 36, 1623-1639.

64 C. Leonhardt, S. Brumm, A. Seifert, G. Cox, A. Lange, T. Rüffer, D. Schaarschmidt, H. Lang, N. Jöhrmann, M. Hietschold, F. Simon and M. Mehring, ChemPlusChem, 2013, 78, 1400-1412.

65 P. Kitschke, A. A. Auer, T. Löschner, A. Seifert, S. Spange, T. Rüffer, H. Lang and M. Mehring, ChemPlusChem, 2014, 79, 1009-1023.
66 C. Leonhardt, S. Brumm, A. Seifert, A. Lange, S. Csihony and M. Mehring, ChemPlusChem, 2014, 79, 1440-1447.

67 P. Kitschke, A. A. Auer, A. Seifert, T. Rüffer, H. Lang and M. Mehring, Inorg. Chim. Acta, 2014, 409, 472-478.

68 P. Kitschke, T. Rüffer, M. Korb, H. Lang, W. B. Schneider, A. A. Auer and M. Mehring, Eur. J. Inorg. Chem., 2015, 2015, 5467-5479.

69 C. S. Weinert, A. E. Fenwick, P. E. Fanwick and I. P. Rothwell, Dalton Trans., 2003, 532-539.

70 A. E. Wetherby Jr, L. R. Göller, A. G. DiPasquale, A. L. Rheingold and C. S. Weinert, Inorg. Chem., 2007, 46, 7579-7586.

71 T. J. Boyle, L. J. Tribby, L. A. M. Ottley and S. M. Han, Eur. J. Inorg. Chem., 2009, 5550-5560.

72 B. Ottenbourgs, P. Adriaensens, R. Carleer, D. Vanderzande and J. Gelan, Polymer, 1998, 39, 5293-5300.

73 B. D. Park and B. Riedl, J. Appl. Polym. Sci., 2000, 77, 12841293.

74 R. L. Bryson, G. R. Hatfield, T. A. Early, A. R. Palmer and G. E. Maciel, Macromolecules, 1983, 16, 1669-1672.

75 J. Pola, R. Fajgar, Z. Bastl and L. Diaz, J. Mater. Chem., 1992, 2, 961-964.

76 P. Y. Timbrell, M. K. Puchert and R. N. Lamb, Surf. Interface Anal., 1994, 21, 731-736.

77 K. Prabhakaran and T. Ogino, Surf. Sci., 1995, 325, 263-271.

78 K. Prabhakaran, F. Maeda, Y. Watanabe and T. Ogino, Appl. Phys. Lett., 2000, 76, 2244-2246.

79 N. A. Tabet, M. A. Salim and A. L. Al-Oteibi, J. Electron Spectrosc. Relat. Phenom., 1999, 101-103, 233-238.

80 N. Tabet, M. Faiz, N. M. Hamdan and Z. Hussain, Surf. Sci., 2003, 523, 68-72.

81 S. Rivillon, Y. J. Chabal, F. Amy and A. Kahn, Appl. Phys. Lett., 2005, 87, 253101.

82 H. Adhikari, P. C. McIntyre, S. Sun, P. Pianetta and C. E. D. Chidsey, Appl. Phys. Lett., 2005, 87, 263109.

83 M. Matsui, H. Murakami, T. Fujioka, A. Ohta, S. Higashi and S. Miyazaki, Microelectron. Eng., 2011, 88, 1549-1552.

84 S. K. Sahari, A. Ohta, M. Matsui, K. Mishima, H. Murakami, S. Higashi and S. Miyazaki, J. Phys.: Conf. Ser., 2013, 417, 012014.

85 C. D. Wagner and A. Joshi, J. Electron Spectrosc. Relat. Phenom., 1988, 47, 283-313.

86 J.-G. Ren, Q.-H. Wu, H. Tang, G. Hong, W. Zhang and S.-T. Lee, J. Mater. Chem. A, 2013, 1, 1821-1826.

87 W. Li, Z. Yang, J. Cheng, X. Zhong, L. Gu and Y. Yu, Nanoscale, 2014, 6, 4532-4537.

88 C. Lastoskie, K. E. Gubbins and N. Quirke, Langmuir, 1993, 9, 2693-2702.

89 C. Lastoskie, K. E. Gubbins and N. Quirke, J. Phys. Chem., 1993, 97, 4786-4796.

90 A. Macias-Garcia, M. A. Diaz-Diez, E. M. Cuerda-Correa, M. Olivares-Marin and J. Ganan-Gomez, Appl. Surf. Sci., 2006, 252, 5972-5975.

91 P. I. Ravikovitch and A. V. Neimark, Langmuir, 2006, 22, 11171-11179.

92 P. I. Ravikovitch, A. Vishnyakov, R. Russo and A. V. Neimark, Langmuir, 2000, 16, 2311-2320. 
93 C. J. Rasmussen, A. Vishnyakov, M. Thommes, B. M. Smarsly, F. Kleitz and A. V. Neimark, Langmuir, 2010, 26, 10147-10157.

94 M. Thommes, R. Kohn and M. Fröba, Appl. Surf. Sci., 2002, 196, 239-249.

95 M. Thommes, R. Kohn and M. Fröba, J. Phys. Chem. B, 2000, 104, 7932-7943.

96 N. U. Hofsløkken and L. Skattebøl, Acta Chem. Scand., 1999, 53, 258-262.

97 B. Zeynizadeh and T. Behyar, Z. Naturforsch., B: J. Chem. Sci., 2005, 60, 453-457.

98 G. M. Sheldrick, Acta Crystallogr., Sect. A: Found. Crystallogr., 2008, 64, 112-122.

99 A. D. Becke, J. Chem. Phys., 1993, 98, 5648-5652.
100 C. Lee, W. Yang and R. G. Parr, Phys. Rev. B: Condens. Matter Mater. Phys., 1988, 37, 785-789.

101 R. Ahlrichs, M. Bär, M. Häser, H. Horn and C. Kölmel, Chem. Phys. Lett., 1989, 162, 165-169.

102 R. Ahlrichs and O. Treutler, J. Chem. Phys., 1995, 102, 346354.

103 M. v. Arnim and R. Ahlrichs, J. Comput. Chem., 1998, 19, 1746-1757.

104 F. Weigend, M. Häser, H. Patzelt and R. Ahlrichs, Chem. Phys. Lett., 1998, 294, 143-152.

105 F. Weigend and R. Ahlrichs, Phys. Chem. Chem. Phys., 2005, 7, 3297-3305.

106 S. Grimme, J. Antony, S. Ehrlich and H. Krieg, J. Chem. Phys., 2010, 132, 154104. 